\title{
Effect of short-term versus long-term grassland management and seasonal variation in organic and conventional dairy farming on the composition of bulk tank milk
}

\author{
S. A. Adler, ${ }^{*} \dagger^{1}$ S. K. Jensen, $\ddagger$ E. Govasmark, ${ }^{\star} \S$ and H. Steinshamn* \\ *Bioforsk - Norwegian Institute for Agricultural and Environmental Research, Organic Food and Farming Division, N-6630 Tingvoll, Norway \\ †Department of Animal and Aquacultural Sciences, Norwegian University of Life Sciences, Arboretveien 6, 1432 Ås, Norway \\ $\ddagger$ Department of Animal Science, Aarhus University, Blichers Allé, 8830 Tjele, Denmark \\ §Department of Plant and Environmental Sciences, Norwegian University of Life Sciences, PO Box 5003, 1432 Ås, Norway
}

\section{ABSTRACT}

Bulk tank milk from 28 dairy farms was sampled every second month for $2 \mathrm{yr}$ to assess the effects of grassland management, production system and season on milk fatty acid (FA) composition, concentrations of fat-soluble vitamins, Se, and milk sensory quality. Grassland management varied in terms of time since establishment. Short-term grassland management (SG) was defined as establishment or reseeding every fourth year or more often, and long-term grassland management (LG) was defined as less frequent establishment or reseeding. Fourteen organic (ORG) dairy farms with either short-term or long-term grassland management were paired with 14 conventional $(\mathrm{CON})$ farms with respect to grassland management. Within ORG farms, SG farms differed from LG farms in herbage botanical composition, but not in concentrate FA concentrations, dry matter intake, or milk yield. Within CON farms, herbage composition, concentrate FA concentrations, dry matter intake, and milk yield showed no or insignificant variations. The ORG farms differed from CON farms in herbage botanical composition, concentrate FA concentrations, concentrate intake, and milk yield. Compared with ORG-LG farms, ORG-SG farms produced milk fat with higher proportions of C10:0 and $\mathrm{C} 12: 0$ associated with higher herbage proportions of legumes (Fabaceae) and lower proportions of other dicotyledon families. Compared with milk from CON farms, milk fat from ORG farms had higher proportions of most saturated FA and all n-3 FA, but lower proportions of $\mathrm{C} 18: 0$ and $\mathrm{C} 18: 1$ cis-9 associated with higher forage proportion and differences in concentrations of FA in concentrates. Compared with the outdoor-feeding periods, the indoor feeding periods yielded milk fat with higher proportions of most shortchain and medium-chain FA and lower proportions of

Received May 24, 2012.

Accepted May 12, 2013.

${ }^{1}$ Corresponding author: steffen.adler@bioforsk.no most C18-FA associated with grazing and higher forage proportions. Milk concentrations of $\alpha$-tocopherol and $\beta$-carotene were lower during the grazing periods. Inclusion of fishmeal in organic concentrates may explain higher Se concentrations in organically produced milk. Milk sensory quality was not affected in this study. In conclusion, grassland management had minor effects on milk composition, and differences between ORG farms and CON farms may be explained by differences in concentrate intake and concentrate FA concentrations. Milk produced on ORG farms versus CON farms and milk produced during the outdoor versus indoor feeding periods had potential health benefits due to FA composition. In contrast, the higher milk-fat proportions of saturated FA in milk from ORG farms may be perceived as negative for human health.

Key words: dairy farm, grassland management, production system, milk composition

\section{INTRODUCTION}

Consumption of dairy products has been claimed to have negative health effects in humans because milk fat has high proportions of SFA, which are understood to contribute to cardiovascular disease and obesity (Appleby et al., 1999; Insel et al., 2007). In contrast, new studies have revealed that high consumption of dairy products may help to prevent coronary heart disease, different types of cancer, and other chronic diseases, although the mechanisms are not understood (Kliem and Givens, 2011). Fat-soluble vitamins are important in human nutrition (Haug et al., 2007) and, besides their nutritional value, they may also improve the oxidative stability of milk fat with high proportions of PUFA (AlMabruk et al., 2004). Diet formulation may influence the milk-fat composition of grazing or silage-fed cows (Chilliard et al., 2001).

Grassland management is likely to affect sward botanical composition, which has been proven to affect milk FA composition (Dewhurst et al., 2003b; Lourenço et al., 2008). Sward botanical composition affects the 
concentrations of fat-soluble vitamins in forages, but also other factors, such as plant maturity (Danielsson et al., 2008) and preservation method (Lindqvist et al., 2012), are important. Milk concentrations of fat-soluble vitamins vary significantly and depend on diet, animal factors, such as breed (McDowell, 2000) and stage of lactation (Jensen et al., 1999), and supplementation. Forage Se concentrations have been reported inadequate to meet the dietary Se requirement in regions with low soil Se concentrations, and thus Se-enriched feed supplements are commonly used (Govasmark et al., 2005).

Compared with conventionally produced milk, organically produced milk has higher fat proportions of C18:3n-3 (Butler et al., 2008; Collomb et al., 2008a), C18:1 trans-11 and C18:2 cis-9,trans-11 (Jahreis et al., 1996; Collomb et al., 2008a), PUFA (Ellis et al., 2006; Collomb et al., 2008a), and lower proportions of n-6 FA (Butler et al., 2008; Collomb et al., 2008a;), C18:0, C18:1 cis-9, and MUFA (Jahreis et al., 1996; Collomb et al., 2008a). The concentrations of $\alpha$-tocopherol and $\beta$-carotene are higher in organic than conventional milk during the outdoor feeding period, but not during the indoor feeding period in the study of Butler et al. (2008). Ellis et al. (2007) reported no differences for these vitamins, but found less retinol in organic milk. The concentrations of $\alpha$-tocopherol and $\beta$-carotene are higher in summer milk than in winter milk (LindmarkMånsson et al., 2003; Ellis et al., 2007). In these studies, the authors suggest a positive effect of grazing compared with feeding silage on fat-soluble vitamins in milk, however, the role of forage type and total diet needs further investigations.

Sward age and composition on dairy farms vary according to conditions that complicate soil tillage necessary for reseeding, such as climate, slope, stone content, field size, or economic costs. The time span after reseeding and other grassland management factors may affect grassland botanical composition (Hopkins, 1986), which, together with differences in dietary supplementation, affect milk FA composition (Dewhurst et al., 2003b), concentrations of fat-soluble vitamins (Bolstad et al., 2007), and Se concentrations in milk. Although previously cited studies indicate specific effects of botanical composition on milk FA and fat-soluble vitamins, to our knowledge no attempts have been made to investigate the effect of botanical composition at the level of farming systems (Ellis et al., 2007; Butler et al., 2008; Collomb et al., 2008a).

The objectives of the present study were to compare the effects of long-term versus short-term grassland management in organic and conventional production systems, compare organic and conventional production systems, and assess seasonal variation on FA composi- tion, fat-soluble vitamin concentrations, sensory quality, and Se concentration in bulk tank milk.

\section{MATERIALS AND METHODS}

\section{Experimental Design}

Twenty-eight dairy farms in central Norway participated in the study in 2007 and 2008. Seven organic (ORG) farms with short-term grassland management (SG), referred to as ORG-SG farms, were paired with 7 conventional (CON) farms with SG, referred to as CON-SG farms, and 7 ORG farms with long-term grassland management (LG), referred to as ORG-LG farms, were paired with $7 \mathrm{CON}$ farms with LG, referred to as CON-LG farms. Grassland management was defined as SG when the grassland fields of a farm were renewed every fourth year or more frequently and as LG when the fields were renewed less frequently. Fields were renewed by soil tillage and seeding. Organic and conventional farms were paired on location and calving pattern, based on information from local extension services. The organic farms were certified by the Norwegian certification body Debio (Bjørkelangen, Norway) according to the EU standards for organic farming (European Commission, 2006). In brief, the standards for organic farming require a minimum forage intake in total DMI $(50 \%$ in the first 3 mo of lactation increasing to $60 \%$ thereafter) and all feeds have to be grown organically (i.e., without the use of synthetic pesticides and synthetic $\mathrm{N}$ fertilizers). Fertilization with animal manure is limited to $170 \mathrm{~kg}$ of N/ha and year. All farms participated in the Norwegian Dairy Herd Recording System and delivered milk to the same dairy company (TINE Norwegian Dairies SA, Oslo, Norway). On all farms, forages were fed ad libitum and allocated concentrate amounts were based on individual milk yields.

\section{On-Farm Analysis, Sampling, and Data Collection}

Data on farm characteristics (Table 1) were collected in farmer interviews and milk production data were collected from the Norwegian Dairy Herd Recording System. Herbage botanical composition before first cut silage in 2007 was estimated on 4 selected fields on each farm by the dry-weight-rank method (Mannetje and Haydock, 1963), modified by Jones and Hargreaves (1979). The selected fields represented overall grassland use including fields that were cut, cut and grazed in combination, or only grazed. Silage and concentrates were sampled twice in each indoor feeding period (February 2007, October 2007, February 2008, December 2008) on each farm. Two milk samples were taken in each sampling month (February, April, June, August, 
Table 1. Characteristics of dairy farms with an organic production system and short-term (ORG-SG) or long-term grassland management (ORG-LG) and dairy farms with a conventional production system and short-term (CON-SG) or long-term grassland management (CON-LG; $\mathrm{n}=7)$

\begin{tabular}{|c|c|c|c|c|c|c|c|c|}
\hline \multirow[b]{3}{*}{ Item } & \multicolumn{8}{|c|}{ Farming system } \\
\hline & \multicolumn{2}{|c|}{ ORG-SG } & \multicolumn{2}{|c|}{ ORG-LG } & \multicolumn{2}{|c|}{ CON-SG } & \multicolumn{2}{|c|}{ CON-LG } \\
\hline & Mean & $\mathrm{SD}$ & Mean & $\mathrm{SD}$ & Mean & $\mathrm{SD}$ & Mean & $\mathrm{SD}$ \\
\hline $\begin{array}{l}\text { Average distance between paired farms, }{ }^{1} \mathrm{~km} \\
\text { Proportion of calvings } \mathrm{s}^{1,2}\end{array}$ & 3.0 & 2.04 & 6.5 & 7.09 & & & & \\
\hline January to March & 0.26 & 0.192 & 0.21 & 0.139 & 0.15 & 0.092 & 0.19 & 0.141 \\
\hline April to June & 0.26 & 0.254 & 0.18 & 0.120 & 0.34 & 0.242 & 0.24 & 0.283 \\
\hline July to September & 0.26 & 0.139 & 0.35 & 0.172 & 0.29 & 0.172 & 0.27 & 0.133 \\
\hline October to December & 0.23 & 0.125 & 0.27 & 0.084 & 0.22 & 0.111 & 0.30 & 0.225 \\
\hline Farm area, ha & 32 & 6.6 & 32 & 11.1 & 27 & 12.1 & 22 & 4.8 \\
\hline Altitude, m & 69 & 39.5 & 106 & 71.6 & 53 & 38.9 & 141 & 125.1 \\
\hline Herd size, cows & 22 & 9.5 & 15 & 3.0 & 18 & 4.8 & 19 & 6.3 \\
\hline Forage area proportion & 0.87 & 0.055 & 0.99 & 0.023 & 0.85 & 0.213 & 1.00 & 0.000 \\
\hline Grassland age, ${ }^{3}$ yr & 3 & 1.0 & 11 & 3.6 & 3 & 0.9 & 10 & 4.1 \\
\hline Date of first cut silage & 12 June & 5.5 & 22 June & 10.8 & 13 June & 4.8 & 18 June & 7.9 \\
\hline Manure, ${ }^{4} \mathrm{~kg}$ of total $\mathrm{N} / \mathrm{ha}$ and $\mathrm{yr}$ & 80 & 27.5 & 101 & 49.5 & 107 & 50.4 & 178 & 94.8 \\
\hline Fertilizer, $\mathrm{kg}$ of $\mathrm{N} / \mathrm{ha}$ and $\mathrm{yr}$ & 0 & & 0 & & 235 & 44.1 & 242 & 13.3 \\
\hline
\end{tabular}

${ }^{1}$ Organic farms were paired with CON farms with respect to grassland management on location and calving pattern.

${ }^{2}$ From 2003 through 2008.

${ }^{3}$ Weighted for field area.

${ }^{4}$ Calculated as $3.1 \mathrm{~kg}$ of $\mathrm{N} / \mathrm{t}$ of manure (Daugstad et al., 2012).

October, December) from stirred bulk tanks after 4 to 6 milkings and transported at $4^{\circ} \mathrm{C}$ to the dairy.

\section{Animals and Diets}

On most farms cows were housed in tiestalls, and on 6 farms, mainly SG farms, in loose-house barns. The cows were mainly fed grass silage-based diets during the indoor feeding periods (October to mid-May), and on all farms cows grazed in the outdoor feeding periods, although many herds also had access to silage. Only herds with Norwegian Red dairy cows were included in the study, and calving time was rather evenly distributed over the year on all farms. Dairy feed rations included forage, concentrates, mineral mixtures, and vitamin mixtures on all farms. Silage fermented in bulk silos or in round bales (proportion of silage fermented in round bales in total silage produced: ORG-SG $=0.36$, ORG-LG $=0.20$, CON-SG $=0.58$, CON-LG $=0.29$ ) was the main forage in the indoor feeding periods. On most farms the herbage was wilted before ensiling. The cows were kept indoors at night on 8 farms (ORG-SG: 1, ORG-LG: 3, CON-SG: 1, CON-LG: 3) during the outdoor feeding periods. Homegrown grains of barley and oats were fed in addition to commercial concentrates on most ORG-SG farms and supplemented with fishmeal on 2 ORG-SG farms.

Commercial concentrates were used on all farms, but ingredients varied; organic mixes contained (on average) barley $29 \%$, wheat $25 \%$, oats $21 \%$, fishmeal $7 \%$, sugarcane molasses $5 \%$, and expeller soybean meal $4 \%$, and conventional mixes contained (on average) barley $36 \%$, oats $15 \%$, solvent-extracted soybean meal $12 \%$, Sorghum (Sorghum bicolor (L.) Moench) 10\%, rape seeds and expeller rape seed meal $8 \%$, sugar beet pulp $8 \%$, sugarcane molasses $7 \%$, rumen protected fat (saturated vegetable FA, mainly C16:0; AkoFeed Gigant 60; Aarhus Karlshamn AB, Malmö, Sweden) 2\%, and vegetable fat (vegetable $\mathrm{FA}$, mainly $\mathrm{C} 18: 1$ cis-9, C16:0; C18:2n-6; AkoFeed Standard; Aarhus Karlshamn AB) $1 \%$. Additionally, on some farms, other feed supplements, such as potato (1 ORG-SG farm), whey (1 ORG-LG farm, 1 CON-SG farm), brewers' grain (1 CON-SG farm), or macroalgae meal (1 ORG-SG farm), were used.

Commercial concentrates contained synthetic vitamins (vitamin A: $1.2-1.5 \mathrm{mg} / \mathrm{kg}$; vitamin E: $30-50$ $\mathrm{mg} / \mathrm{kg}$ ) and mineral sodiumselenite (25-40 mg Se/kg). Additionally, most farms supplemented the dairy cows with about $100 \mathrm{~g} / \mathrm{cow}$ of mineral mixtures (e.g., Natura Minovit Drøv and Pluss Multitilskudd, Felleskjøpet Agri, Gardermoen, Norway), containing synthetic vitamins [vitamin A $(0.12 \mathrm{mg} / \mathrm{g})$, vitamin E $(2.0 \mathrm{mg} / \mathrm{g})$ ] and mineral sodiumselenite $(25 \mu \mathrm{g}$ of $\mathrm{Se} / \mathrm{g})$. Fishmeal used in organic commercial concentrates or given as supplement contained $3.6 \mathrm{mg}$ of $\mathrm{Se} / \mathrm{kg}$ of DM, although no information is available on the daily amount of mineral mixtures or fishmeal fed.

\section{Analysis Methods}

Sample Preparation and Chemical Analysis of Forage and Concentrates. Feed samples were stored 
at $-20^{\circ} \mathrm{C}$, freeze-dried (Christ LCM-2, Beta 1-16 and Christ LOC-1m, Alpha 1-4, Martin Christ, Osterode am Harz, Germany; Hetosicc, Birkerød, Denmark), milled (1.0-mm screen; Retsch SM 100, Retsch GmbH, Haan, Germany), and then re-stored at $-20^{\circ} \mathrm{C}$ in plastic bags before analysis of chemical constituents. Forage was analyzed at the Dairy One Inc. Forage Testing Laboratory (Ithaca, NY) for ash by the AOAC method (942.05.), N by the AOAC method (990.03), soluble protein by sodium borate-sodium phosphate buffer procedure on a TruMac N Macro Determinator (Leco, St. Joseph, MI; Roe and Sniffen, 1990), ether extract by the AOAC method (2003.05; AOAC, 1990), NDF by the method of Van Soest et al. (1991) with heat-stable amylase and sodium sulfite, and in vitro true digestibility by the ANKOM DaisyII Filter Bag Technique (Ankom Technology, Macedon, NY) after incubation for $48 \mathrm{~h}$.

Feed FA were extracted by the Röse-Gottlieb method (Molkentin and Precht, 1995) and analyzed as FA methyl esters (FAME) on GC (Thermo Finnigan Focus, Thermo Fisher Scientific Inc., Waltham, MA), equipped with a column of $105 \mathrm{~m} \times 0.25 \mathrm{~mm}$ i.d. and $0.2 \mu \mathrm{m}$ of film thickness (Restek RTX-2330, Restek Corporation, Bellefonte, PA). Fatty acids were quantified by comparison with external standards.

Sample Preparation and Chemical Analysis of Milk. Milk samples intended for analysis of FA composition, fat-soluble vitamin concentrations, and Se concentrations were frozen $\left(-20^{\circ} \mathrm{C}\right)$ immediately after arriving at the dairy. Milk samples intended for analysis of gross composition, urea, and FFA were preserved with 2-bromo-2-nitropropane-1,3-diol (Bronopol, D\&F Inc., Dublin, CA) and analyzed by a Fourier transformed infrared spectroscopy milk analyzer (MilkoScan 6000 FTIR, Foss, Hillerød, Denmark). Milk samples intended for assessment of sensory quality were stored at $4^{\circ} \mathrm{C}$. For analysis of FA, fat was extracted from milk with chloroform and methanol according to Bligh and Dyer (1959) and analyzed as FAME, as described by Jensen and Nielsen (1996) by GC (Hewlett Packard 6890 series, Agilent Technologies, Palo Alto, CA) equipped with an automatic on-column injector (Hewlett Packard 7673; split ratio $4.325: 1$ ), a capillary column of $30 \mathrm{~m} \times 320$ $\mu \mathrm{m}$ i.d. and $0.25-\mu \mathrm{m}$ film thickness (Omegawax, Supelco 4-293-415, Sigma-Aldrich, St. Louis, MO), and a flame-ionization detector. The FA C17:0 was used as external standard. Fat-soluble vitamins were extracted and analyzed by HPLC as described by Jensen and Nielsen (1996) and Jensen et al. (1998). A PerkinElmer HS-5-Silica column $(4.0 \times 125 \mathrm{~mm}$; Waltham, MA $)$ was used for analyses of $\alpha$-tocopherol and retinol and a Supelco amino column $(4.6 \times 250 \mathrm{~mm}$; Sigma-Aldrich $)$ was used for analysis of $\beta$-carotene. Total milk Se con- centrations were determined by inductively coupled plasma mass spectrometry (PerkinElmer, Elan 6000). Five milliliters of fresh milk were digested at $240^{\circ} \mathrm{C}$ for 40 min using an ultraclave (UltraCLAVE 3, Milestone, Shelton, CT) in $3.5 \mathrm{~mL}$ of distilled ultrapure $\mathrm{HNO}_{3}$ (Merck, Whitehouse Station, NJ). The samples were dried and redissolved in $20 \mathrm{~mL}$ of $2 \%$ ethanol and $1 \% \mathrm{HNO}_{3}$ and stored for 6 wk before analysis. Tellur was used as internal standard. The standard reference material whole milk powder 8435 (0.131 SD, $0.014 \mu \mathrm{g}$ $\mathrm{Se} / \mathrm{g}$ ) from the National Institute of Standards and Technology (Gaithersburg, MD) was digested with $\mathrm{HNO}_{3}$ in triplicate and analyzed for quality assurance and control purposes. The relative standard deviation based on counting statistics was less than $2 \%$.

Assessment of Sensory Quality. Test panels of at least 2 trained assessors (TINE Norwegian Dairies SA) evaluated raw bulk tank milk odor and taste on a 5 -point scale, where $1=$ milk with serious deviation from normal taste and $5=$ milk with no deviation from normal taste. Milk samples were assessed the day after delivery to the dairy plants.

\section{Calculations}

Estimates of feed intake were based on the participating herds' data in the Norwegian Dairy Herd Recording System. Daily concentrate DMI per cow was weighted by milk production on farm level as (sum of individual concentrate intakes $\times$ sum of individual milk yields)/(sum of individual milk yields). Daily forage net energy intake per cow was estimated as net energy requirement for maintenance $\left(0.0424 \times 600 \mathrm{~kg}\right.$ of $\mathrm{BW}^{0.75}$; (Van Es, 1978), added net energy requirement for milk production $\left(0.44 \times \mathrm{ECM}+0.0007293 \times \mathrm{ECM}^{2} ;\right.$ Van Der Honing and Alderman, 1988), and subtracted net energy intake of concentrates (individual concentrate intakes $\times$ net energy concentration based on product declaration). Forage DMI was estimated by dividing the estimated forage net energy intake by the energy concentration in forage samples, estimated from in vitro true digestibility analyses. In the indoor feeding periods for months without feed samples, average values were calculated, and in the outdoor feeding periods a feed table value was used $\left(\mathrm{NE}_{\mathrm{L}}: 6.86 \mathrm{SD}, 0.386 \mathrm{MJ} /\right.$ $\mathrm{kg}$ of DM; Anonymous, 2012). Apparent de novo FA synthesis was calculated as the daily secretion of the sum of C4:0 to C14:1c9 plus the sum of C15:0 to $17: 1 \mathrm{c} 9$ $\times 0.5$, as a share (approximately $50 \%$ ) of the latter FA is blood derived.

\section{Statistical Analysis}

Feed composition, DMI, milk yield, milk composition, and milk sensory quality were analyzed using the 
MIXED model procedure by SAS (SAS, 2009). Statistical model 1 was

$$
\begin{aligned}
Y_{i j k l m n}=\mu+ & G_{i}+P(G)_{i j}+M_{k}+(G M)_{i k}+[M P(G)]_{i j k} \\
& +f(G, P)_{i j l}+t(G)_{i m}+e_{i j k l m n},
\end{aligned}
$$

where $Y$ were the individual dependent variables for DMI, feed composition, milk yield, and milk composition $(n=1-336) ; \mu$ was the average of all observations; $G$ was the fixed effect of grassland management $(i=1$, 2 ; where $1=\mathrm{SG}$ and $2=\mathrm{LG}) ; P(G)$ was the fixed effect of production system within $G(j=1,2$; where $1=$ ORG and $2=\mathrm{CON}) ; M$ was the fixed effect of month $(k=1-12$; where $1=$ February 2007, $2=$ April 2007, 3 $=$ June 2007, $4=$ August 2007, $5=$ October 2007, $6=$ December 2007, $7=$ February 2008, $8=$ April 2008, 9 $=$ June 2008, $10=$ August 2008, $11=$ October 2008, 12 $=$ December 2008); $(G M)$ and $[M P(G)]$ were interactions of the fixed effects; $f$ was the random effect of farm within $G$ and $P(l=1$ through 28$) ; t$ was the random effect of farm pair within $G(m=1-14)$; and $e_{i j k l m n}$ were the random residual errors, assumed to be independent and $N\left(0, \sigma_{e}^{2}\right)$. Observations for month within farm were treated as repeated observations. Contrasts were calculated for the effects of ORG-SG versus ORG-LG, CON-SG versus CON-LG, ORG versus CON, and indoor $(k=1,2,5,6,7,8,11,12)$ versus outdoor feeding periods $(k=3,4,9,10)$. Differences between means were tested with the Tukey-Kramer test. For analysis of feed chemical composition the statistical model 2 was

$$
\begin{aligned}
Y_{i j k l m n} & =\mu+G_{i}+P(G)_{i j}+m_{k}+f(G, P)_{i j l} \\
& +t(G)_{i m}+s(m, f)_{i j k l}+e_{i j k l m n},
\end{aligned}
$$

where $Y, \mu, G, P(G), f(G, P), t(G)$, and $e$ were as specified for model $1 ; m$ was the random effect of month $(k=$ $1,5,7,12$; number of month as specified for $M$ in model 1 ); and $s$ was the random effect of sample within $m$ and $f(l=1-113)$. For analysis of botanical composition the GLIMMIX procedure in SAS (SAS, 2009), which fits generalized linear mixed models, was used. Statistical model 2 was applied with the modification that $s(f)$ was the number of fields within farm assessed $(l=1-4)$. To find correlations between proportions of botanical families in the herbage, concentrate DMI and milkfat proportions of selected FA a principal component analysis was performed by the PRINCOMP procedure in SAS (SAS, 2009).
RESULTS

\section{Botanical and Chemical Composition of Diets}

The herbage botanical composition of fields that were cut or both cut and grazed differed between ORGSG and ORG-LG farms and between ORG farms and CON farms, although differences between CON-SG and CON-LG farms were small (Table 2). Grassland on ORG-SG farms contained more $(P=0.001)$ legumes and less $(P=0.009)$ dandelion than on ORG-LG farms, and grassland on ORG farms contained less $(P$ $=<0.001)$ grass and more $(P=<0.001)$ legumes than on CON farms. For fields solely used as pastures, no differences were found between farming systems. In pastures, the proportions averaged $655 \mathrm{~g}$ of $\mathrm{DM} / \mathrm{kg}$ of $\mathrm{DM}$ for grasses, $53 \mathrm{~g}$ of $\mathrm{DM} / \mathrm{kg}$ of DM for legumes, and $292 \mathrm{~g}$ of $\mathrm{DM} / \mathrm{kg}$ of DM for other dicotyledons.

Despite differences in the botanical composition of fields used for silage production, small differences were found in silage chemical composition between farming systems (Table 3). Compared with silages from ORGLG, silages from ORG-SG had lower $(P=0.04)$ concentrations of $\mathrm{C} 18: 3 \mathrm{n}-3$. Compared with silages from CON, silages from ORG had less CP $(P<0.001)$ and crude fat $(P=0.04)$ and more NFC $(P<0.001)$. The FA composition of concentrates did not differ between ORG-SG and ORG-LG or between CON-SG and CONLG, but large differences were found between ORG and CON (Table 4). Compared with concentrates used on CON farms, concentrates used on ORG farms had less $(P<0.001) \mathrm{C} 18: 0$ and $\mathrm{C} 18: 1$ cis-9, and more $(P<$ 0.001) C18:3n-3 and C22:6n-3.

\section{Effects of Grassland Management and Production System on Feed Intake, Milk Yield, and Milk Composition}

Grassland management had small effects on DMI, daily milk yields, and milk composition, whereas production system had pronounced effects. Compared with milk from ORG-LG, milk from ORG-SG had higher protein concentrations $(P<0.05)$ and higher milk-fat proportions of the SFA C9:0, C10:0, C11:0, C12:0 $(P \leq$ $0.01), \mathrm{C} 14: 1$ cis-9 $(P=0.005), \mathrm{C} 22: 1$ cis-11 $(P=0.005)$, and C22:6n-3 $(P<0.001)$, and lower proportions of $\mathrm{C} 17: 1$ cis-9 $(P=0.01), \mathrm{C} 18: 4 \mathrm{n}-3(P=0.007)$ and $\mathrm{C} 24: 0$ $(P=0.005)$, whereas only small differences were found in milk from CON-SG compared with CON-LG (Tables 5 and 6). The secretion of the apparently de novo synthesized FA C10:0 through C14:1 cis-9 was higher $(P=$ 0.04) for ORG-SG than for ORG-LG (Table 7). Grass- 
Table 2. Herbage botanical composition of fields for cutting and combined cutting or grazing ( $\mathrm{g}$ of DM/kg of DM) before first cut in 2007 on dairy farms with an organic production system (ORG) and short-term (ORG-SG) or long-term grassland management (ORG-LG) and dairy farms with conventional production system (CON) and short-term (CON-SG) or long-term grassland management $(\mathrm{CON}-\mathrm{LG} ; 7$ farms $\times 3$ fields; $\mathrm{n}=21$ )

\begin{tabular}{|c|c|c|c|c|c|c|c|c|c|c|}
\hline \multirow[b]{2}{*}{ Item } & \multicolumn{4}{|c|}{ Farming system } & \multirow[b]{2}{*}{ SEM } & \multicolumn{5}{|c|}{$P$-value ${ }^{1}$} \\
\hline & ORG-SG & ORG-LG & CON-SG & CON-LG & & $\mathrm{G}^{2}$ & $\mathrm{P}(\mathrm{G})^{3}$ & $\begin{array}{c}\text { ORG-SG } \\
\text { vs. ORG-LG }\end{array}$ & $\begin{array}{c}\text { CON-SG } \\
\text { vs. CON-LG }\end{array}$ & $\begin{array}{c}\text { ORG } \\
\text { vs. } \mathrm{CON}^{6}\end{array}$ \\
\hline Grasses (Poaceae; 19 spp.) & $642^{\mathrm{bc}}$ & $505^{\mathrm{c}}$ & $918^{\mathrm{a}}$ & $818^{\mathrm{ab}}$ & 53.5 & 0.037 & $<0.001$ & 0.084 & NS & $<0.001$ \\
\hline Timothy (Phleum pratense L.) & $342^{\mathrm{ab}}$ & $128^{\mathrm{b}}$ & $495^{\mathrm{a}}$ & $249^{\mathrm{b}}$ & 51.6 & $<0.001$ & 0.061 & 0.007 & 0.003 & 0.021 \\
\hline Meadow fescue (Festuca pratensis Huds.) & 101 & 79 & 154 & 141 & 41.8 & NS & NS & NS & NS & NS \\
\hline Perennial ryegrass (Lolium perenne L.) & 69 & 31 & 97 & 22 & 29.5 & 0.067 & NS & NS & 0.087 & NS \\
\hline Smooth meadowgrass (Poa pratensis $\mathrm{L}$.) & 50 & 44 & 40 & 48 & 31.0 & NS & NS & NS & NS & NS \\
\hline Rough meadowgrass (Poa trivialis L.) & 25 & 45 & 29 & 126 & 27.2 & 0.078 & 0.093 & NS & 0.020 & 0.099 \\
\hline Common couch (Elytrigia repens L.) & 34 & 8 & 64 & 112 & 27.9 & NS & 0.037 & NS & NS & 0.024 \\
\hline Other grasses & 20 & 169 & 37 & 121 & 35.9 & 0.013 & NS & 0.007 & NS & NS \\
\hline Legumes (Fabaceae; 8 spp.) & $265^{\mathrm{a}}$ & $141^{\mathrm{b}}$ & $32^{\mathrm{c}}$ & $15^{\mathrm{c}}$ & 23.3 & 0.006 & $<0.001$ & 0.001 & NS & $<0.001$ \\
\hline Red clover (Trifolium pratense L.) & $174^{\mathrm{a}}$ & $94^{\mathrm{ab}}$ & $20^{\mathrm{b}}$ & $12^{\mathrm{b}}$ & 23.4 & 0.062 & $<0.001$ & 0.018 & NS & $<0.001$ \\
\hline White clover (Trifolium repens L.) & $58^{\mathrm{a}}$ & $49^{\mathrm{ab}}$ & $12^{\mathrm{ab}}$ & $3^{\mathrm{b}}$ & 12.5 & NS & 0.011 & NS & NS & 0.003 \\
\hline Other legumes & 33 & 0 & 0 & 0 & 9.3 & 0.095 & 0.069 & 0.022 & NS & 0.091 \\
\hline Other botanical families (20 spp.) & $94^{\mathrm{b}}$ & $357^{\mathrm{a}}$ & $51^{\mathrm{b}}$ & $167^{\mathrm{ab}}$ & 56.7 & 0.003 & 0.072 & 0.003 & NS & 0.051 \\
\hline Northern dock (Rumex longifolius DC.) & 36 & 94 & 15 & 40 & 24.6 & NS & NS & NS & NS & NS \\
\hline Dandelion (Taraxacum spp.) & $33^{\mathrm{ab}}$ & $92^{\mathrm{a}}$ & $14^{\mathrm{b}}$ & $27^{\mathrm{b}}$ & 14.5 & 0.034 & 0.016 & 0.009 & NS & 0.010 \\
\hline Common sorrel (Rumex acetosa $\mathrm{L}$.) & 3 & 71 & 1 & 56 & 28.4 & 0.090 & NS & NS & NS & NS \\
\hline Creeping buttercup (Ranunculus repens L.) & 8 & 48 & 2 & 22 & 14.2 & 0.048 & NS & 0.060 & NS & NS \\
\hline Meadow buttercup (Ranunculus acris L.) & 5 & 22 & 2 & 4 & 7.3 & NS & NS & NS & NS & NS \\
\hline Other spp. & 7 & 32 & 17 & 18 & 11.0 & NS & NS & NS & NS & NS \\
\hline Number of spp. per field & $15.1^{\mathrm{ab}}$ & $17.3^{\mathrm{a}}$ & $12.3^{\mathrm{b}}$ & $13.2^{\mathrm{b}}$ & 0.87 & 0.092 & 0.002 & 0.091 & NS & 0.001 \\
\hline
\end{tabular}

${ }^{\mathrm{a}-\mathrm{c}}$ Means within a row with different letters differ (Tukey-Kramer test, $P<0.05$ ).

${ }^{1}$ Nonsignificant $=P>0.10$.

${ }^{2}$ Effect of grassland management.

${ }^{3}$ Effect of production system within grassland management.

${ }^{4}$ Contrast of ORG-SG vs. ORG-LG.

${ }^{5}$ Contrast of CON-SG vs. CON-LG.

${ }^{6}$ Contrast of ORG vs. CON. 
Table 3. Silage chemical composition, feed values, and FA composition on dairy farms with an organic production system (ORG) and short-term (ORG-SG) or long-term grassland management (ORG-LG) and dairy farms with a conventional production system (CON) and short-term (CON-SG) or long-term grassland management (CON-LG)

\begin{tabular}{|c|c|c|c|c|c|c|c|c|c|c|}
\hline \multirow[b]{2}{*}{ Item } & \multicolumn{5}{|c|}{ Farming system } & \multicolumn{5}{|c|}{$P$-value ${ }^{1}$} \\
\hline & ORG-SG & ORG-LG & CON-SG & CON-LG & SEM & $\mathrm{G}^{2}$ & $\mathrm{P}(\mathrm{G})^{3}$ & $\begin{array}{l}\text { ORG-SG } \\
\text { vs. ORG- } \\
\text { LG }^{4}\end{array}$ & $\begin{array}{c}\text { CON-SG } \\
\text { vs. CON-LG }\end{array}$ & $\begin{array}{l}\text { ORG } \\
\text { vs. } \mathrm{CON}^{6}\end{array}$ \\
\hline $\mathrm{n}$ & 31 & 25 & 27 & 29 & & & & & & \\
\hline \multicolumn{11}{|l|}{ Chemical composition and feed value } \\
\hline $\mathrm{DM}, \mathrm{g} / \mathrm{kg}$ & 285 & 271 & 258 & 254 & 19.8 & NS & NS & NS & NS & NS \\
\hline $\mathrm{CP}, \mathrm{g} / \mathrm{kg}$ of $\mathrm{DM}$ & $136^{\mathrm{b}}$ & $140^{\mathrm{b}}$ & $170^{\mathrm{a}}$ & $168^{\mathrm{a}}$ & 6.7 & NS & $<0.001$ & NS & NS & $<0.001$ \\
\hline Soluble protein, $\mathrm{g} / \mathrm{kg}$ of $\mathrm{CP}$ & $606^{\mathrm{ab}}$ & $532^{\mathrm{b}}$ & $638^{\mathrm{a}}$ & $595^{\mathrm{ab}}$ & 23.7 & 0.058 & 0.049 & 0.036 & NS & 0.021 \\
\hline Crude fat, $\mathrm{g} / \mathrm{kg}$ of DM & 44 & 51 & 52 & 55 & 3.8 & NS & 0.085 & 0.085 & NS & 0.038 \\
\hline $\mathrm{NDF}, \mathrm{g} / \mathrm{kg}$ of DM & 555 & 561 & 574 & 589 & 14.5 & NS & NS & NS & NS & 0.075 \\
\hline $\mathrm{ADF}, \mathrm{g} / \mathrm{kg}$ of $\mathrm{DM}$ & 366 & 374 & 373 & 384 & 8.4 & NS & NS & NS & NS & NS \\
\hline NFC, $\mathrm{g} / \mathrm{kg}$ of DM & $223^{\mathrm{a}}$ & $214^{\mathrm{a}}$ & $174^{\mathrm{b}}$ & $176^{\mathrm{b}}$ & $\begin{array}{r}0.4 \\
13.8\end{array}$ & NS & 0.001 & NS & NS & $<0.001$ \\
\hline $\mathrm{OM}, \mathrm{g} / \mathrm{kg}$ of $\mathrm{DM}$ & $922^{\mathrm{ab}}$ & $927^{\mathrm{ab}}$ & $918^{\mathrm{b}}$ & $936^{\mathrm{a}}$ & $\begin{array}{r}10.0 \\
5.4\end{array}$ & 0.065 & NS & NS & 0.012 & NS \\
\hline In vitro true digestibility $(48 \mathrm{~h}), \mathrm{g} / \mathrm{kg}$ of DM & 822 & 802 & 820 & 808 & 10.9 & NS & NS & NS & NS & NS \\
\hline \multirow{2}{*}{\multicolumn{11}{|c|}{$\mathrm{FA}, \mathrm{g} / \mathrm{kg}$ of DM }} \\
\hline & & & & & & & & & & \\
\hline C16:0 & 3.86 & 4.21 & 4.13 & 4.19 & 0.605 & NS & NS & NS & NS & NS \\
\hline C18:0 & 0.39 & 0.41 & 0.35 & 0.36 & 0.062 & NS & NS & NS & NS & 0.076 \\
\hline C18:1 cis-9 & 0.79 & 1.10 & 0.69 & 0.84 & 0.177 & 0.057 & NS & 0.047 & NS & 0.089 \\
\hline C18:2n-6 & 3.66 & 4.29 & 3.75 & 3.82 & 0.660 & NS & NS & 0.083 & NS & NS \\
\hline C18:3n-3 & 8.25 & 10.25 & 10.71 & 10.35 & 1.603 & NS & 0.042 & 0.044 & NS & 0.067 \\
\hline Total FA & 22.8 & 26.9 & 26.5 & 26.8 & 3.67 & NS & NS & 0.048 & NS & NS \\
\hline \multicolumn{11}{|c|}{$\overline{{ }^{\mathrm{a}-\mathrm{c}} \text { Means within a row with different letters differ (Tukey-Kramer test, } P<0.05 \text { ). }}$} \\
\hline \multirow{2}{*}{\multicolumn{11}{|c|}{${ }^{1}$ Nonsignificant $=P>0.10$}} \\
\hline & \\
\hline \multirow{2}{*}{\multicolumn{11}{|c|}{${ }^{3} \mathrm{Effect}$ of production system within grassland management. }} \\
\hline & & & & & & & & & & \\
\hline \multicolumn{11}{|l|}{${ }^{5}$ Contrast of CON-SG vs. CON-LG. } \\
\hline \multicolumn{11}{|l|}{${ }^{6}$ Contrast of ORG vs. CON. } \\
\hline & & & & & & & & & & \\
\hline & & & & & & & & & & \\
\hline & & & & & & & & & & \\
\hline & & & & & & & & & & \\
\hline & & & & & & & & & & \\
\hline
\end{tabular}


Table 4. Concentrate FA composition on dairy farms with an organic production system (ORG) and short-term (ORG-SG) or long-term grassland management (ORG-LG) and dairy farms with a conventional production system (CON) and short-term (CON-SG) or long-term grassland management (CON-LG) during the indoor feeding periods

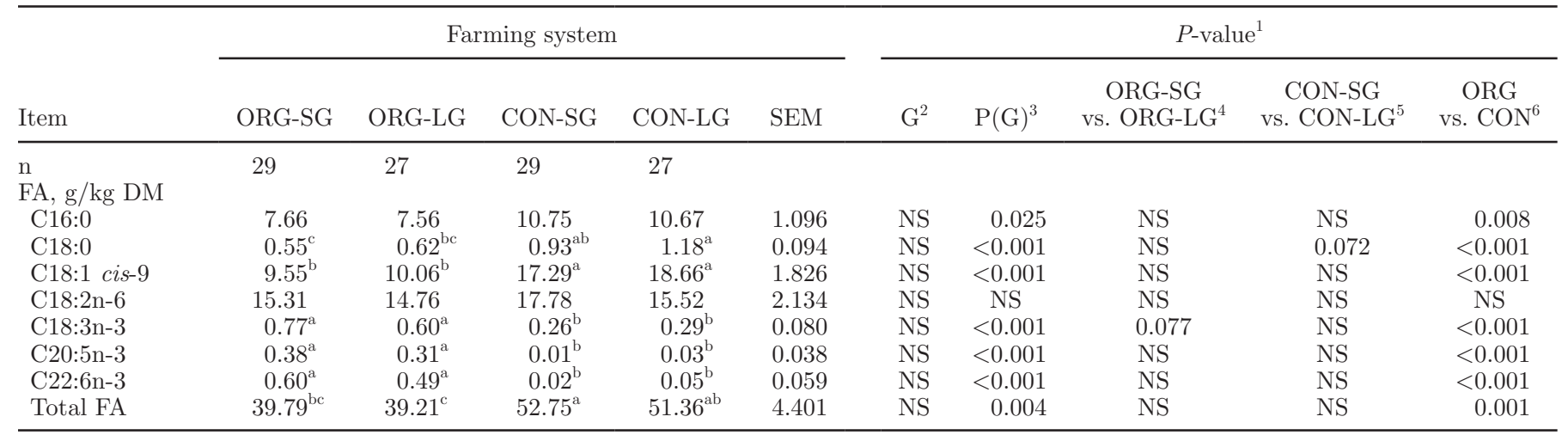

\footnotetext{
${ }^{1}$ Nonsignificant $=P>0.10$.

${ }^{2}$ Effect of grassland management.

${ }^{3}$ Effect of production system within grassland management.

${ }^{4}$ Contrast of ORG-SG vs. ORG-LG.

${ }^{5}$ Contrast of CON-SG vs. CON-LG.

${ }^{6}$ Contrast of ORG vs. CON.
}

${ }^{\mathrm{a}-\mathrm{c}}$ Means within a row with different letters differ (Tukey-Kramer test, $P<0.05$ ).

land management within the production system did not affect milk concentrations of fat-soluble vitamins, Se, and milk sensory quality (Table 8).

Compared with cows on CON farms, cows on ORG farms had lower daily concentrate intakes (means = ORG: $4.5 \mathrm{~kg}$ of DM/d, CON: $6.4 \mathrm{~kg}$ of DM/d; $P=$ 0.001), lower milk yields (ORG: $20.0 \mathrm{~kg} / \mathrm{d}$; CON: 22.5 $\mathrm{kg} / \mathrm{d} ; P=0.03)$, and lower milk urea concentrations (ORG: $4.0 \mathrm{mmol} / \mathrm{L}, \mathrm{CON}: 5.4 \mathrm{mmol} / \mathrm{L} ; P<0.001$ ). Milk fat from ORG farms had higher proportions of most SFA, C18:1 trans (includes several coeluting trans FA) FA (ORG: $29.2 \mathrm{~g} / \mathrm{kg}$ of FAME, CON: $25.3 \mathrm{~g} / \mathrm{kg}$ of FAME; $P=0.03$ ) and all $\mathrm{n}-3 \mathrm{FA}$ than milk fat from CON-farms. This resulted in a lower n-6:n-3 FA ratio in milk from ORG farms (2.1 vs. 3.0; $P<0.001)$. The proportions of C18:0 (ORG: $103.0 \mathrm{~g} / \mathrm{kg}$ of FAME, CON: $129.8 \mathrm{~g} / \mathrm{kg}$ of FAME; $P<0.001$ ) and C18:1 cis-9 (ORG: $214.7 \mathrm{~g} / \mathrm{kg}$ of FAME, CON: $2.44 .8 \mathrm{~g} / \mathrm{kg}$ of FAME; $P$ $<0.001$ ) were lower in milk fat from ORG farms than CON farms. Calculated as proportions in total C18-FA in milk fat, ORG farms had higher proportions of most unsaturated C18-FA and lower proportions of C18:0 ( $P$ $<0.001$ ) compared with CON farms (Table 9). Milk concentrations of Se were higher $(P=0.009)$ on ORG farms than on CON farms. The concentrations of fatsoluble vitamins and sensory quality were not affected by production system.

\section{Effect of Season on Feed Intake, Milk Yield, and Milk Composition}

Total DMI was higher $(P<0.001)$ during the indoor feeding season than the outdoor feeding season, but for- age proportion and daily milk yields were not affected. Milk concentrations of fat $(P<0.001)$ and FFA $(P<$ 0.001) were higher during the indoor feeding periods. Compared with milk from the outdoor feeding periods, milk from the indoor feeding periods had higher proportions of most short-chain and medium-chain SFA and lower proportions of most C18-FA, total MUFA, total PUFA, total n-6 FA, and total n-3 FA. The concentrations of $\alpha$-tocopherol $(P<0.001)$ and $\beta$-carotene $(P$ $=0.02)$ were higher during the indoor feeding periods than during outdoor feeding. Season did not affect milk Se concentrations and milk sensory quality.

The effects of grassland management and production system on milk FA composition were consistent across season, in general. For some FA, significant interaction effects were observed between month and management factors; however, these interactions did not alter the general effects of month or management factors.

\section{Correlation of Herbage Botanical Composition and FA Composition in Milk}

In the principal component analysis of herbage botanical composition, which examined concentrate DMI and the proportions of selected FA in milk fat, the principal component 1 explained $43 \%$ of the total variation and generally differentiated ORG farms from CON farms with the exception of 1 CON-LG farm (Figure 1). Principal component 2 explained $24 \%$ of the total variation and differentiated most ORG-SG farms from ORG-LG farms, but not CON-SG farms from CON-LG farms. The herbage proportion of the 
Table 5. Average DMI, milk yield, and milk gross composition on dairy farms with an organic production system (ORG) and short-term (ORG-SG) or long-term grassland management (ORG-LG) and dairy farms with a conventional production system (CON) and short-term (CON-SG) or long-term grassland management (CON-LG) during indoor (IN) and outdoor feeding periods (OUT)

\begin{tabular}{|c|c|c|c|c|c|c|c|c|c|c|c|c|c|c|c|c|c|}
\hline \multirow[b]{2}{*}{ Item } & \multicolumn{5}{|c|}{ Farming system } & \multicolumn{3}{|c|}{ Season } & \multicolumn{9}{|c|}{$P$-value ${ }^{1}$} \\
\hline & ORG-SG & ORG-LG & CON-SG & CON-LG & SEM & IN & OUT & SEM & $\mathrm{G}^{2}$ & $\begin{array}{c}\mathrm{P} \\
(\mathrm{G})^{3}\end{array}$ & $\mathrm{M}^{4}$ & $\begin{array}{c}\mathrm{G} \\
\times \mathrm{M}^{5}\end{array}$ & $\begin{array}{l}\mathrm{P}(\mathrm{G}) \\
\times \mathrm{M}^{6}\end{array}$ & $\begin{array}{l}\text { ORG-SG } \\
\text { vs. } \\
\text { ORG-LG }\end{array}$ & $\begin{array}{l}\text { CON-SG } \\
\text { vs. } \\
\text { CON-LG }\end{array}$ & $\begin{array}{l}\text { ORG } \\
\text { vs. } \\
\text { CON }^{9}\end{array}$ & $\begin{array}{l}\text { IN } \\
\text { vs. } \\
\text { OUT }^{10}\end{array}$ \\
\hline $\mathrm{n}$ & 84 & 84 & 84 & 84 & & 224 & 112 & & & & & & & & & & \\
\hline $\begin{array}{l}\text { Forage proportion, }{ }^{11,12} \\
\mathrm{~g} / \mathrm{kg} \text { of total DMI } \\
\text { DMI }{ }^{11} \mathrm{~kg} / \mathrm{d}\end{array}$ & $705^{\mathrm{a}}$ & $699^{\mathrm{a}}$ & $646^{\mathrm{ab}}$ & $585^{\mathrm{b}}$ & 24.6 & 658 & 660 & 20.6 & NS & 0.003 & NS & NS & NS & NS & 0.094 & 0.001 & NS \\
\hline Forage ${ }^{12 / \mathrm{u}}$ & 11.5 & 11.2 & 11.7 & 9.5 & 0.58 & 11.4 & 10.2 & 0.45 & 0.061 & NS & $<0.001$ & NS & NS & NS & 0.012 & NS & $<0.001$ \\
\hline Concentrates & $4.6^{\mathrm{b}}$ & $4.4^{\mathrm{b}}$ & $6.2^{\mathrm{ab}}$ & $6.5^{\mathrm{a}}$ & 0.46 & 5.7 & 4.9 & 0.30 & NS & 0.004 & $<0.001$ & NS & NS & NS & NS & 0.001 & $<0.001$ \\
\hline Total & $16.0^{\mathrm{ab}}$ & $15.4^{\mathrm{b}}$ & $17.8^{\mathrm{a}}$ & $15.9^{\mathrm{ab}}$ & 0.58 & 16.9 & 15.0 & 0.50 & NS & 0.004 & $<0.001$ & NS & NS & NS & 0.024 & 0.057 & $<0.001$ \\
\hline Milk yield, $\mathrm{kg} / \mathrm{d}$ & $20.9^{\mathrm{ab}}$ & $19.0^{\mathrm{b}}$ & $23.9^{\mathrm{a}}$ & $21.1^{\mathrm{ab}}$ & 1.13 & 21.1 & 21.5 & 0.82 & 0.048 & 0.095 & NS & NS & NS & NS & 0.094 & 0.034 & NS \\
\hline $\mathrm{ECM},{ }^{13} \mathrm{~kg} / \mathrm{d}$ & $21.6^{\mathrm{ab}}$ & $19.8^{\mathrm{b}}$ & $24.8^{\mathrm{a}}$ & $21.8^{\mathrm{ab}}$ & 1.13 & 22.0 & 22.0 & 0.80 & 0.048 & 0.089 & NS & NS & NS & NS & 0.073 & 0.034 & NS \\
\hline Fat, $\mathrm{g} / \mathrm{kg}$ & 41.2 & 39.4 & 40.9 & 40.5 & 0.61 & 40.9 & 39.6 & 0.51 & NS & NS & $<0.001$ & NS & NS & 0.053 & NS & NS & $<0.001$ \\
\hline Protein, g/kg & $34.7^{\mathrm{a}}$ & $33.0^{\mathrm{b}}$ & $34.2^{\mathrm{ab}}$ & $33.4^{\mathrm{ab}}$ & 0.36 & 33.8 & 33.8 & 0.33 & 0.021 & NS & 0.031 & NS & NS & 0.004 & NS & NS & NS \\
\hline Lactose, $\mathrm{g} / \mathrm{kg}$ & 47.0 & 46.6 & 46.7 & 46.8 & 0.20 & 46.6 & 47.1 & 0.16 & NS & NS & $<0.001$ & NS & NS & NS & NS & NS & $<0.001$ \\
\hline $\mathrm{FFA}, \mathrm{mEq} / \mathrm{L}$ & 0.46 & 0.53 & 0.52 & 0.58 & 0.040 & 0.56 & 0.46 & 0.034 & NS & NS & $<0.001$ & NS & NS & NS & NS & NS & $<0.001$ \\
\hline Urea, mmol/L & $4.2^{\mathrm{b}}$ & $3.8^{\mathrm{b}}$ & $5.4^{\mathrm{a}}$ & $5.5^{\mathrm{a}}$ & 0.21 & 4.7 & 4.7 & 0.17 & NS & $<0.001$ & $<0.001$ & 0.084 & 0.013 & NS & NS & $<0.001$ & NS \\
\hline
\end{tabular}

a,b Means within a row with different letters differ (Tukey-Kramer test, $P<0.05$ ).

${ }^{1}$ Nonsignificant $=P>0.10$.

${ }^{2}$ Effect of grassland management.

${ }^{3}$ Effect of production system within grassland management.

${ }^{4}$ Effect of month.

${ }^{5}$ Interaction between grassland management and month.

¿ $\quad{ }^{6}$ Interaction between production system within grassland management and month.

$\begin{array}{ll}{ }_{\bar{\Xi}} & { }^{7} \text { Contrast of ORG-SG vs. ORG-LG. } \\ \stackrel{8}{0} & { }^{8} \text { Contrast of CON-SG vs. CON-LG. }\end{array}$

을 ${ }^{9}$ Contrast of ORG vs. CON.

${ }^{10}$ Contrast of IN vs. OUT.

₹ $\quad{ }^{11}$ Weighted for individual milk yield.

กิ. ${ }^{12}$ Estimates based on dairy cows' net energy requirements for maintenance and production.

م ${ }^{13}$ Calculated as kilograms of milk $\times(0.01+0.0122 \times \mathrm{g}$ of fat $/ \mathrm{kg}$ of milk $+0.0077 \times \mathrm{g}$ of protein $/ \mathrm{kg}$ of milk $+0.0053 \times \mathrm{g}$ of lactose $/ \mathrm{kg}$ of milk $)$. 
Table 6. Fatty acid composition and total FA in milk from dairy farms with an organic production system (ORG) and short-term (ORG-SG) or long-term grassland management (ORG-LG) and dairy farms with a conventional production system (CON) and short-term (CON-SG) or long-term grassland management (CON-LG) during the indoor (IN) and outdoor feeding periods (OUT)

$$
\text { Farming system }
$$

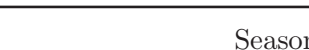

$P$-value ${ }^{1}$

ORG-SG CON-SG ORG IN $\mathrm{n}$ C4:0 C6:0

C8:0

C9:0

C10:0
C11:0

C12:0

C13:0

C14:0

C14:1 cis-9

C15:0

C16:1 cis-9

C16:1 cis-7

C17:1 cis-9

C18:0

C18:1 cis-9

C18:1 cis-11

C18:1 trans

C18:2 cis-9,trans- 11

C18:2 trans- 10, cis- 12

C18:3n-6

C18:3n-3

C18:4n-3

C20:0

C20:1 cis-9

C20:2n-6

C20:3n-6

C20:3n-3

C20:4n-6

C20:5n-3

$\mathrm{C} 22: 0$

$\mathrm{C} 22: 1$ cis- 11

C22:1 cis-13

C22:5n-6 ORG-SG ORG-LG CON-SG CON-LG SEM

\begin{tabular}{|c|c|c|c|c|c|c|c|c|c|c|c|c|c|c|c|c|}
\hline 84 & 84 & 84 & 84 & & 224 & 112 & & & & & & & & & & \\
\hline 38.3 & 39.1 & 37.7 & 40.1 & 0.75 & 39.1 & 38.1 & 1.07 & 0.072 & NS & $<0.001$ & NS & NS & NS & 0.035 & NS & 0.096 \\
\hline 23.6 & 22.8 & 22.4 & 22.8 & 0.50 & 23.3 & 22.1 & 0.48 & NS & NS & $<0.001$ & NS & NS & NS & NS & NS & $<0.001$ \\
\hline 14.3 & 13.4 & 13.2 & 13.3 & 0.48 & 13.6 & 13.5 & 0.51 & NS & 0.086 & $<0.001$ & 0.019 & NS & NS & NS & 0.078 & NS \\
\hline $0.1^{\mathrm{a}}$ & $0.1^{\mathrm{b}}$ & $0.1^{\mathrm{b}}$ & $0.1^{\mathrm{b}}$ & 0.01 & 0.1 & 0.1 & 0.01 & 0.067 & 0.013 & $<0.001$ & 0.092 & 0.008 & 0.010 & NS & 0.021 & $<0.001$ \\
\hline $33.0^{\mathrm{a}}$ & $28.9^{\mathrm{b}}$ & $28.9^{\mathrm{b}}$ & $27.7^{\mathrm{b}}$ & 0.94 & 30.0 & 28.9 & 0.86 & 0.034 & 0.005 & $<0.001$ & NS & NS & 0.006 & NS & 0.003 & 0.009 \\
\hline $0.4^{\mathrm{a}}$ & $0.3^{\mathrm{b}}$ & $0.3^{\mathrm{b}}$ & $0.2^{\mathrm{b}}$ & 0.02 & 0.3 & 0.2 & 0.03 & 0.038 & 0.002 & $<0.001$ & NS & NS & 0.008 & NS & 0.002 & 0.001 \\
\hline $37.6^{\mathrm{a}}$ & $32.9^{\mathrm{b}}$ & $32.2^{\mathrm{b}}$ & $30.5^{\mathrm{b}}$ & 1.12 & 33.8 & 32.2 & 0.98 & 0.032 & 0.001 & $<0.001$ & NS & 0.054 & 0.007 & NS & 0.001 & 0.001 \\
\hline $1.0^{\mathrm{a}}$ & $0.9^{\mathrm{a}}$ & $0.8^{\mathrm{b}}$ & $0.8^{\mathrm{b}}$ & 0.03 & 0.9 & 0.8 & 0.04 & NS & $<0.001$ & $<0.001$ & NS & NS & NS & NS & $<0.001$ & 0.001 \\
\hline $124.2^{\mathrm{a}}$ & $117.4^{\mathrm{ab}}$ & $112.4^{\mathrm{bc}}$ & $108.8^{\mathrm{c}}$ & 2.38 & 119.2 & 108.7 & 2.11 & 0.098 & $<0.001$ & $<0.001$ & NS & NS & 0.057 & NS & $<0.001$ & $<0.001$ \\
\hline $10.6^{\mathrm{a}}$ & $9.5^{\mathrm{b}}$ & $9.3^{\mathrm{b}}$ & $8.7^{\mathrm{b}}$ & 0.25 & 10.0 & 8.6 & 0.29 & 0.002 & $<0.001$ & $<0.001$ & NS & NS & 0.005 & 0.088 & $<0.001$ & $<0.001$ \\
\hline $11.7^{\mathrm{ab}}$ & $12.3^{\mathrm{a}}$ & $10.2^{\mathrm{c}}$ & $10.5^{\mathrm{bc}}$ & 0.33 & 11.5 & 10.5 & 0.29 & NS & $<0.001$ & $<0.001$ & NS & NS & NS & NS & $<0.001$ & $<0.001$ \\
\hline $308.7^{\mathrm{a}}$ & $305.0^{\mathrm{a}}$ & $280.8^{\mathrm{b}}$ & $277.8^{\mathrm{b}}$ & 4.65 & 306.1 & 266.9 & 4.34 & NS & $<0.001$ & $<0.001$ & NS & NS & NS & NS & $<0.001$ & $<0.001$ \\
\hline $15.8^{\mathrm{a}}$ & $16.0^{\mathrm{a}}$ & $14.0^{\mathrm{b}}$ & $13.5^{\mathrm{b}}$ & 0.45 & 14.7 & 15.1 & 0.41 & NS & $<0.001$ & 0.004 & NS & NS & NS & NS & $<0.001$ & 0.035 \\
\hline 1.6 & 1.5 & 1.6 & 1.8 & 0.13 & 1.5 & 1.9 & 0.21 & NS & NS & NS & NS & NS & NS & NS & NS & 0.003 \\
\hline $3.5^{\mathrm{ab}}$ & $4.0^{\mathrm{a}}$ & $3.3^{\mathrm{b}}$ & $3.4^{\mathrm{b}}$ & 0.13 & 3.5 & 3.7 & 0.11 & 0.0208 & 0.009 & $<0.001$ & NS & 0.023 & 0.014 & NS & 0.004 & $<0.001$ \\
\hline $99.8^{\mathrm{b}}$ & $106.3^{\mathrm{b}}$ & $127.6^{\mathrm{a}}$ & $132.0^{\mathrm{a}}$ & 3.17 & 112.7 & 123.9 & 2.68 & 0.0956 & $<0.001$ & $<0.001$ & NS & NS & NS & NS & $<0.001$ & $<0.001$ \\
\hline $208.3^{\mathrm{b}}$ & $221.2^{\mathrm{b}}$ & $244.1^{\mathrm{a}}$ & $245.5^{\mathrm{a}}$ & 5.20 & 221.0 & 247.2 & 4.92 & NS & $<0.001$ & $<0.001$ & NS & NS & 0.096 & NS & $<0.001$ & $<0.001$ \\
\hline 8.9 & 8.3 & 9.0 & 8.9 & 0.32 & 8.4 & 9.6 & 0.30 & NS & NS & $<0.001$ & NS & NS & NS & NS & NS & $<0.001$ \\
\hline 28.9 & 29.5 & 24.6 & 26.0 & 1.77 & 21.8 & 35.3 & 1.40 & NS & 0.100 & $<0.001$ & 0.049 & 0.008 & NS & NS & 0.034 & $<0.001$ \\
\hline 18.1 & 17.8 & 19.2 & 18.4 & 0.60 & 17.5 & 20.1 & 0.45 & NS & NS & $<0.001$ & NS & NS & NS & NS & NS & $<0.001$ \\
\hline 6.9 & 7.6 & 6.8 & 6.4 & 0.57 & 6.0 & 8.7 & 0.44 & NS & NS & $<0.001$ & NS & NS & NS & NS & NS & $<0.001$ \\
\hline 0.2 & 0.3 & 0.2 & 0.2 & 0.05 & 0.2 & 0.2 & 0.05 & NS & NS & $<0.001$ & 0.020 & NS & 0.062 & NS & NS & 0.024 \\
\hline 1.1 & 1.2 & 1.0 & 1.2 & 0.07 & 1.1 & 1.2 & 0.10 & NS & NS & $<0.001$ & 0.021 & NS & NS & NS & NS & 0.035 \\
\hline $7.0^{\mathrm{a}}$ & $7.1^{\mathrm{a}}$ & $5.3^{\mathrm{b}}$ & $6.1^{\mathrm{ab}}$ & 0.34 & 5.9 & 7.4 & 0.28 & NS & 0.002 & $<0.001$ & NS & NS & NS & NS & 0.001 & $<0.001$ \\
\hline $0.4^{\mathrm{ab}}$ & $0.6^{\mathrm{a}}$ & $0.4^{\mathrm{b}}$ & $0.4^{\mathrm{b}}$ & 0.05 & 0.4 & 0.5 & 0.06 & 0.095 & 0.009 & $<0.001$ & NS & NS & 0.007 & NS & 0.012 & NS \\
\hline $2.7^{\mathrm{a}}$ & $2.7^{\mathrm{a}}$ & $2.0^{\mathrm{b}}$ & $2.2^{\mathrm{b}}$ & 0.11 & 2.5 & 2.3 & 0.03 & NS & $<0.001$ & 0.002 & NS & 0.033 & NS & NS & $<0.001$ & 0.001 \\
\hline $3.1^{\mathrm{a}}$ & $3.1^{\mathrm{a}}$ & $2.2^{\mathrm{b}}$ & $2.4^{\mathrm{b}}$ & 0.16 & 2.7 & 2.7 & 0.16 & NS & $<0.001$ & $<0.001$ & NS & NS & NS & NS & $<0.001$ & NS \\
\hline 0.3 & 0.3 & 0.2 & 0.3 & 0.04 & 0.3 & 0.2 & 0.05 & NS & NS & $<0.001$ & NS & NS & NS & NS & NS & $<0.001$ \\
\hline $0.5^{\mathrm{b}}$ & $0.6^{\mathrm{ab}}$ & $0.7^{\mathrm{a}}$ & $0.6^{\mathrm{ab}}$ & 0.05 & 0.5 & 0.7 & 0.08 & NS & 0.022 & NS & NS & NS & NS & NS & 0.016 & 0.009 \\
\hline 0.2 & & 0.1 & 0.2 & 0.02 & 0.2 & 0.1 & 0.02 & NS & NS & $<0.001$ & NS & NS & NS & NS & 0.045 & $<0.001$ \\
\hline $0.9^{\mathrm{b}}$ & $1.0^{\mathrm{ab}}$ & $1.1^{\mathrm{a}}$ & $1.1^{\mathrm{ab}}$ & 0.05 & 1.0 & 1.1 & 0.07 & NS & 0.030 & NS & NS & NS & NS & NS & 0.057 & NS \\
\hline $0.9^{\mathrm{a}}$ & $0.9^{\mathrm{a}}$ & $0.6^{\mathrm{b}}$ & $0.7^{\mathrm{b}}$ & 0.03 & 0.8 & 0.8 & 0.03 & NS & $<0.001$ & $<0.001$ & NS & 0.086 & NS & 0.040 & $<0.001$ & $<0.001$ \\
\hline $1.3^{\mathrm{a}}$ & $1.4^{\mathrm{a}}$ & $0.8^{\mathrm{b}}$ & $0.9^{\mathrm{b}}$ & 0.07 & 1.1 & 1.1 & 0.09 & NS & $<0.001$ & NS & 0.100 & 0.071 & NS & NS & $<0.001$ & NS \\
\hline $1.0^{\mathrm{a}}$ & $0.8^{\mathrm{b}}$ & $0.2^{\mathrm{c}}$ & $0.2^{\mathrm{c}}$ & 0.06 & 0.6 & 0.5 & 0.06 & NS & $<0.001$ & $<0.001$ & NS & 0.072 & 0.005 & NS & $<0.001$ & 0.001 \\
\hline 0.2 & 0.2 & 0.1 & 0.1 & 0.03 & 0.2 & 0.2 & 0.05 & NS & 0.025 & NS & NS & NS & NS & NS & 0.007 & NS \\
\hline $0.4^{\mathrm{c}}$ & $0.4^{\mathrm{bc}}$ & $0.5^{\mathrm{ab}}$ & $0.6^{\mathrm{a}}$ & 0.03 & 0.5 & 0.5 & 0.03 & NS & $<0.001$ & $<0.001$ & 0.070 & NS & NS & NS & $<0.001$ & 0.041 \\
\hline $1.0^{\mathrm{a}}$ & $1.0^{\mathrm{a}}$ & $0.8^{\mathrm{b}}$ & $0.9^{\mathrm{ab}}$ & 0.05 & 0.9 & 0.9 & 0.04 & NS & $<0.001$ & $<0.001$ & NS & NS & NS & 0.080 & $<0.001$ & 0.027 \\
\hline
\end{tabular}

C22:5n-3

$\begin{array}{lllll}0.9^{\mathrm{ab}} & 0.05 & 0.9 & 0.9 & 0.04\end{array}$

$<0.001<0.001 \quad$ NS NS 
grass family was positively correlated with concentrate DMI $(\mathrm{r}=0.64 ; P<0.001)$ and negatively correlated with herbage proportion of the knotweed family $\left(\mathrm{Po}_{\mathrm{O}}\right.$ lygonaceae; $\mathrm{r}=-0.72 ; P<0.001)$, the buttercup family (Ranunculaceae; $\mathrm{r}=-0.72 ; P<0.001$ ) and the aster family (Asteraceae; $\mathrm{r}=-0.73 ; P<0.001$ ). Furthermore, the herbage grass family was negatively correlated with the milk-fat proportions of C18:1 trans FA $(\mathrm{r}=-0.57 ; P=0.002), \mathrm{C} 18: 2$ cis-9, trans $-11(\mathrm{r}$ $=-0.53 ; P<0.004)$, and C18:3n-3 $(\mathrm{r}=-0.83 ; P$ $<0.001)$. The forage proportion of the legume family was positively correlated with the milk FA proportions of $\mathrm{C} 12: 0(\mathrm{r}=0.65 ; P<0.001), \mathrm{C} 14: 0(\mathrm{r}=0.63 ; P<$ $0.001), \mathrm{C} 16: 0(\mathrm{r}=0.60 ; P<0.001)$, and $\mathrm{C} 22: 6 \mathrm{n}-3(\mathrm{r}$ $=0.82 ; P<0.001)$, and negatively correlated with the milk FA proportions of $\mathrm{C} 18: 0(\mathrm{r}=0.71 ; P<0.001)$ and $\mathrm{C} 18: 1$ cis-9 $(\mathrm{r}=0.71 ; P<0.001$; Figure 2$)$. The CON-LG farm differing from the other CON-LG farms in the principal component analysis had less grasses $(258 \mathrm{~g} / \mathrm{kg}$ of DM), less legumes $(3 \mathrm{~g} / \mathrm{kg}$ of DM), more nonlegume dicotyledons $(739 \mathrm{~g} / \mathrm{kg}$ of $\mathrm{DM})$, and lower concentrate level (4.6 kg of DM/d) per cow compared with the other CON-LG farms. Thus, this CON-LG farm had a botanical composition similar to that of ORG-LG farms. Milk fat proportions of SFA $(649 \mathrm{~g} / \mathrm{kg}$ of FAME) were lower and MUFA (306 g/ $\mathrm{kg}$ of FAME) and PUFA (46 g/ $\mathrm{kg}$ of FAME) were higher in milk from this farm than the average of CON-LG farms.

\section{DISCUSSION}

The observed differences in botanical composition between the farming systems may be due to differences in seed mixtures used, harvesting management, $\mathrm{N}$-fertilization level, or herbicide use. On CON farms, the use of synthetic N-fertilizers most likely boosted plant growth from early spring, which may explain higher proportions of grass and $\mathrm{CP}$ concentrations in silage compared with ORG farms. Slightly higher $\mathrm{NE}_{\mathrm{L}}$ concentrations in silage and higher total DMI, and thereby higher total $\mathrm{NE}_{\mathrm{L}}$ intake on ORG-SG farms than on ORG-LG farms, may have stimulated microbial protein synthesis, explaining the higher protein concentrations in milk from ORG-SG than ORG-LG farms, in accordance with Coulon and Rémond (1991). The lower silage concentrations of C18:3n-3 for ORGSG compared with ORG-LG may be related to red clover proportion, because concentrations of C18:3n-3 tend to be lower in fresh legumes than fresh grasses (Boufaïed et al., 2003). It has also been shown that the loss of unsaturated FA during silage fermentation may be higher for legumes than grasses (Knicky et al., 2012). 
Table 7. Total FA concentration in milk, calculated sums and ratios of FA, and desaturase index in milk from dairy farms with an organic production system (ORG) and shortterm (ORG-SG) or long-term grassland management (ORG-LG) and dairy farms with a conventional production system (CON) and short-term (CON-SG) or long-term grassland management (CON-LG) during the indoor (IN) and outdoor feeding periods (OUT)

\begin{tabular}{|c|c|c|c|c|c|c|c|c|c|c|c|c|c|c|c|c|c|}
\hline \multirow[b]{2}{*}{ Item } & \multicolumn{4}{|c|}{ Farming system } & \multicolumn{3}{|c|}{ Season } & \multirow[b]{2}{*}{ SEM } & \multicolumn{9}{|c|}{$P$-value ${ }^{1}$} \\
\hline & $\begin{array}{l}\text { ORG- } \\
\text { SG }\end{array}$ & $\begin{array}{l}\text { ORG- } \\
\text { LG }\end{array}$ & $\begin{array}{l}\mathrm{CON}- \\
\mathrm{SG}\end{array}$ & $\begin{array}{l}\mathrm{CON}- \\
\mathrm{LG}\end{array}$ & SEM & IN & OUT & & $\mathrm{G}^{2}$ & $\begin{array}{c}\mathrm{P} \\
(\mathrm{G})^{3}\end{array}$ & $\mathrm{M}^{4}$ & $\begin{aligned} & \mathrm{G} \\
\times \mathrm{M}^{5} & \end{aligned}$ & $\begin{array}{l}\mathrm{P}(\mathrm{G}) \\
\times \mathrm{M}^{6}\end{array}$ & $\begin{array}{l}\text { ORG-SG } \\
\text { vs. } \\
\text { ORG-LG }^{7}\end{array}$ & $\begin{array}{l}\text { CON-SG } \\
\text { vs. } \\
\text { CON-LG }\end{array}$ & $\begin{array}{l}\text { ORG } \\
\text { vs. } \\
\text { CON }^{9}\end{array}$ & $\begin{array}{l}\text { IN } \\
\text { vs. } \\
\text { OUT }^{10}\end{array}$ \\
\hline $\mathrm{n}$ & 84 & 84 & 84 & 84 & & 224 & 112 & & & & & & & & & & \\
\hline $\begin{array}{l}\text { Total FA, } \mathrm{g} / \mathrm{kg} \text { of milk } \\
\text { Calculated sums of FA, }\end{array}$ & 33.1 & 31.8 & 32.9 & 33.0 & 0.56 & 33.2 & 31.6 & 0.72 & NS & NS & $<0.001$ & NS & NS & NS & NS & NS & $<0.001$ \\
\hline Total SFA & $697.1^{\mathrm{a}}$ & $684.1^{\mathrm{ab}}$ & $669.8^{\mathrm{b}}$ & $668.3^{\mathrm{b}}$ & 6.42 & 694.7 & 650.0 & 5.68 & NS & 0.004 & $<0.001$ & NS & NS & NS & NS & 0.001 & $<0.001$ \\
\hline Total MUFA & $264.0^{\mathrm{b}}$ & $276.2^{\mathrm{ab}}$ & $293.1^{\mathrm{a}}$ & $294.7^{\mathrm{a}}$ & 5.90 & 269.4 & 307.3 & 5.28 & NS & $<0.001$ & $<0.001$ & NS & NS & NS & NS & $<0.001$ & $<0.001$ \\
\hline Total PUFA & 38.9 & 39.7 & 37.1 & 37.0 & 1.12 & 35.9 & 42.7 & 0.93 & NS & NS & $<0.001$ & NS & NS & NS & NS & 0.052 & $<0.001$ \\
\hline Total n- 6 FA & 21.3 & 21.3 & 22.8 & 22.1 & 0.68 & 21.0 & 23.7 & 0.52 & NS & NS & $<0.001$ & 0.012 & NS & NS & NS & NS & $<0.001$ \\
\hline Total n-3 FA & $10.6^{\mathrm{a}}$ & $10.5^{\mathrm{a}}$ & $7.3^{\mathrm{b}}$ & $8.4^{\mathrm{b}}$ & 0.42 & 8.7 & 10.1 & 0.34 & NS & $<0.001$ & $<0.001$ & NS & NS & NS & 0.087 & $<0.001$ & $<0.001$ \\
\hline $\begin{array}{l}\text { Apparently de novo } \\
\text { synthesized FA, }{ }^{11} \mathrm{~g} / \mathrm{d}\end{array}$ & & & & & & & & & & & & & & & & & \\
\hline $\mathrm{C} 4: 0$ to $\mathrm{C} 9: 0$ & 53 & 46 & 58 & 53 & 3.5 & 54 & 50 & 2.81 & NS & NS & $<0.001$ & NS & NS & NS & NS & 0.073 & 0.038 \\
\hline $\mathrm{C} 10: 0$ to $\mathrm{C} 14: 1$ cis -9 & 141 & 114 & 144 & 123 & 8.7 & 135 & 121 & 6.35 & 0.022 & NS & $<0.001$ & NS & NS & 0.038 & NS & NS & $<0.001$ \\
\hline $\mathrm{C} 15: 0$ to $\mathrm{C} 17: 1$ cis-9 & 117 & 102 & 121 & 107 & 6.5 & 117 & 101 & 4.79 & 0.050 & NS & $<0.001$ & NS & NS & NS & NS & NS & $<0.001$ \\
\hline $\begin{array}{l}\text { Calculated ratios of FA } \\
\text { n-6:n-3 FA } \\
\text { Desaturase index }\end{array}$ & $2.1^{\mathrm{b}}$ & $2.1^{\mathrm{b}}$ & $3.2^{\mathrm{a}}$ & $2.8^{\mathrm{a}}$ & 0.16 & 2.6 & 2.5 & 0.15 & NS & $<0.001$ & 0.008 & NS & NS & NS & 0.051 & $<0.001$ & NS \\
\hline $\mathrm{C} 14^{12}$ & 0.078 & 0.075 & 0.076 & 0.073 & 0.0016 & 0.077 & 0.073 & 0.0016 & 0.073 & NS & $<0.001$ & NS & NS & NS & NS & NS & $<0.001$ \\
\hline $\mathrm{C} 16^{13}$ & 0.049 & 0.050 & 0.048 & 0.047 & 0.0014 & 0.046 & 0.054 & 0.0013 & NS & NS & $<0.001$ & NS & 0.093 & NS & NS & 0.055 & $<0.001$ \\
\hline
\end{tabular}

${ }_{\mathrm{a}, \mathrm{b}}$ Means within a row with different letters differ (Tukey-Kramer test, $P<0.05$ ).

${ }^{1}$ Nonsignificant $=P>0.10$.

${ }^{2}$ Effect of grassland management.

${ }^{3}$ Effect of production system within grassland management.

${ }^{4}$ Effect of month.

${ }^{5}$ Interaction between grassland management and month.

${ }^{6}$ Interaction between production system within grassland management and month.

${ }^{7}$ Contrast of ORG-SG vs. ORG-LG.

${ }^{8}$ Contrast of CON-SG vs. CON-LG.

${ }^{9}$ Contrast of ORG vs. CON

${ }^{10}$ Contrast of IN vs. OUT.

${ }^{11} \Sigma$ de novo synthesized FA and for C15 to C17: $0.5 \times \Sigma$ de novo synthesized FA.

${ }^{12} \mathrm{C} 14: 1$ cis-9/(C14:1 cis-9 + C14:0).

${ }^{13} \mathrm{C} 16: 1$ cis-9 $\times(\mathrm{C} 16: 1$ cis $-9+\mathrm{C} 16: 0)$. 
Table 8. Milk concentrations of fat-soluble vitamins, Se, and milk sensory quality from dairy farms with an organic production system (ORG) and short-term (ORG-SG) or longterm grassland management (ORG-LG) and dairy farms with a conventional production system (CON) and short-term (CON-SG) or long-term grassland management (CON-LG) during the indoor (IN) and outdoor feeding period (OUT)

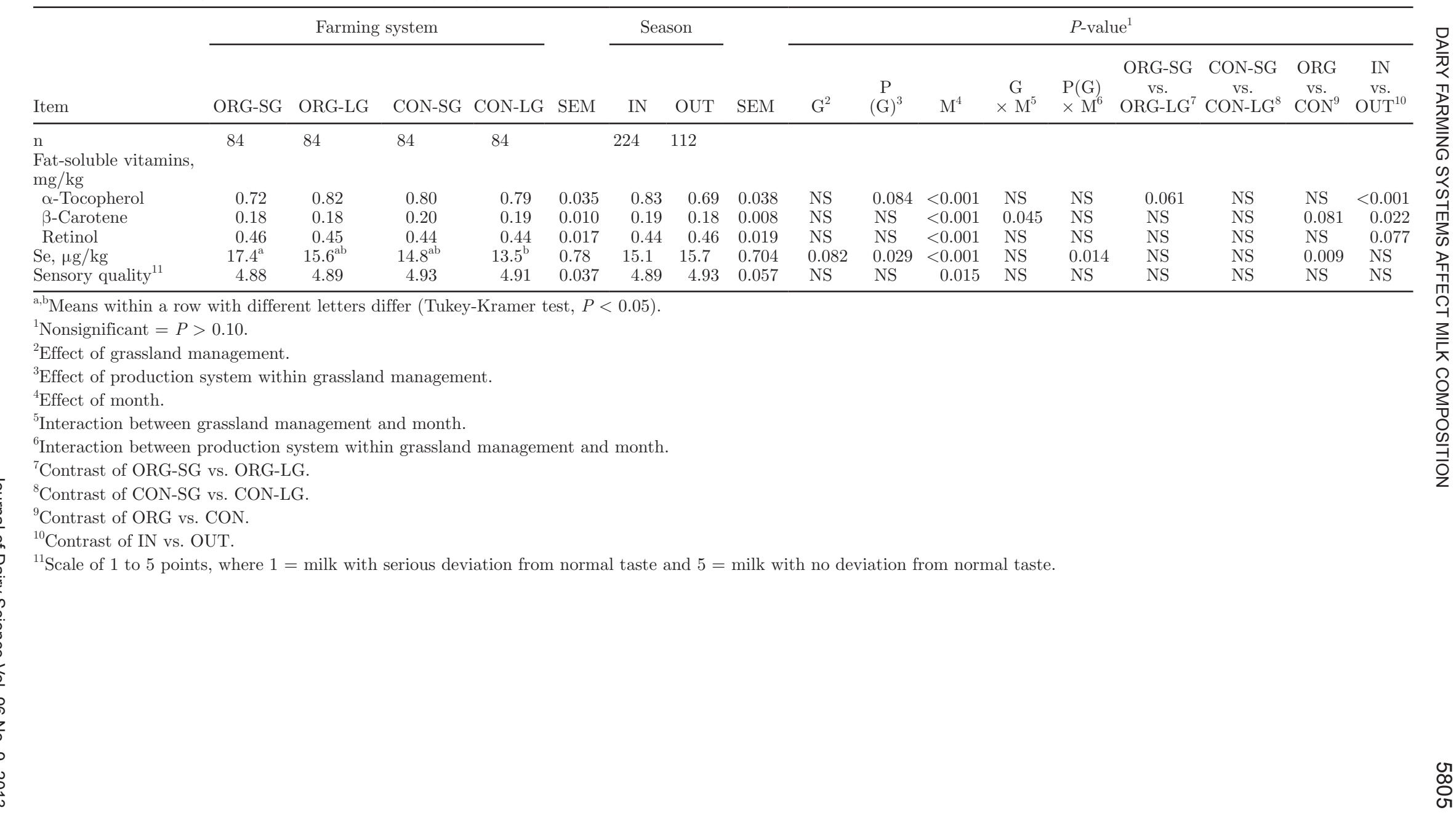


Intake of CP determines milk urea concentrations to a large extent (Broderick, 2003). Higher forage proportions and lower forage $\mathrm{CP}$ concentrations resulted in lower intakes of energy and $\mathrm{CP}$ and, thereby, lower milk yields and milk urea concentrations on ORG farms than on CON farms.

\section{Effects on Milk FA Composition}

Small differences in milk FA composition between ORG-SG and ORG-LG and between CON-SG and CON-LG are in accordance with Dewhurst et al. (2003b) and Steinshamn and Thuen (2008), who compared red and white clover grass silages. In contrast to the present study, however, silage containing red clover has, in most studies, increased milk fat proportions of C18:3n-3 compared with silages containing white clover or grass (Steinshamn and Thuen, 2008; Moorby et al., 2009). A possible explanation may be that the differences in clover species proportions were too small in the present study. Higher milk fat proportions of C10:0 and C12:0 for ORG-SG versus ORG-LG may be related to increased de novo synthesis, and higher milk fat proportions of $\mathrm{C} 22: 1$ cis-11 and $\mathrm{C} 22: 6 \mathrm{n}-3$ may be related to higher intake of fishmeal, in accordance with Donovan et al. (2000).

The increased milk fat proportions of total SFA for ORG is in accordance with the results from the indoor feeding period in the study of Butler et al. (2008), whereas Ellis et al. (2006) and Collomb et al. (2008a) found no differences between organic and conventional bulk tank milk. Increased de novo synthesis can be caused by increased concentrate level (Dewhurst et al., 2003b) or by low-fiber diets (Alzahal et al., 2009). However, in the present study, the daily secretion of apparently de novo synthesized FA was not affected by production system. Higher proportions of SFA may also be caused by increased mobilization of C16:0 from adipose tissue due to longer periods of feeding below energy balance in early lactation (Palmquist et al., 1993). As the plane of nutrition was lower for ORG farms than on CON farms, the cows on ORG farms were likely to be in lower energy status, which may explain the higher proportions of $\mathrm{C} 16: 0$ in milk from ORG farms than in the milk from CON farms.

Lower milk fat proportions of $\mathrm{C} 18: 0$ and $\mathrm{C} 18: 1$ cis9 in milk from ORG farms than CON farms are in accordance with Jahreis et al. (1996) and Collomb et al. (2008a), and is most likely related to differences in quantity and quality of fat sources used in the concentrates. A lower proportion of C18:2n-6 is in accordance with Jahreis et al. (1996). Higher milk fat proportions of C18:3n-3 and total n-3 FA for ORG than CON are in accordance with Ellis et al. (2006) and Collomb et al.

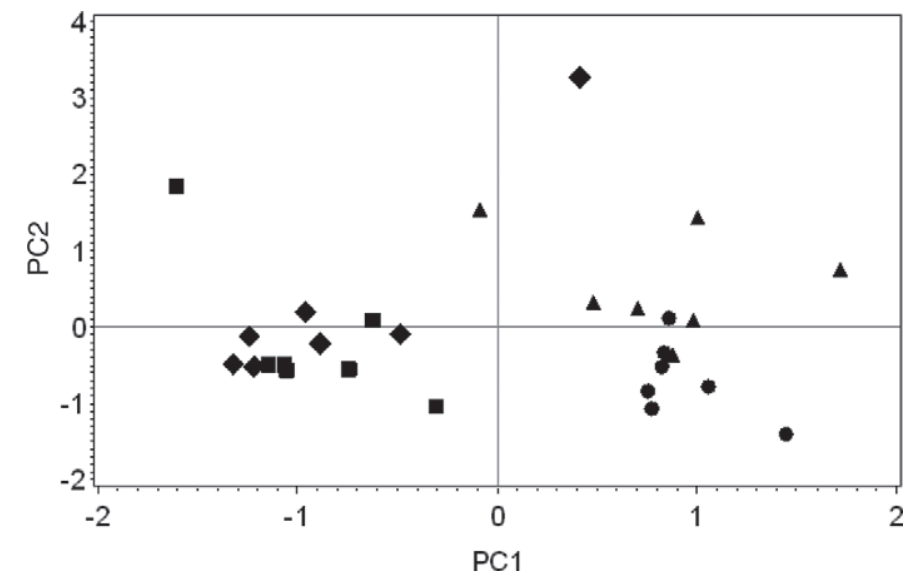

Figure 1. Score plot for first and second principal components (PC1 vs. $\mathrm{PC} 2$ ) for dairy farms with an organic production system and short-term (ORG-SG, $)$ or long-term grassland management (ORGLG, $\Delta$ ) and dairy farms with a conventional production system and short-term (CON-SG, $)$ or long-term grassland management (CONLG, ) based on variables of milk fat proportions of selected FA, herbage proportions of botanical families, and cows' daily concentrate DMI (means over 2 yr for 28 farms).

(2008a), and may be explained by higher concentrate concentrations of $\mathrm{C} 18: 3 \mathrm{n}-3$, higher dietary forage proportion (Dewhurst et al. 2003b; Steinshamn and Thuen 2008), or higher herbage proportions of red and white clover, which can reduce rumen biohydrogenation of C18:3n-3 as reported by Dewhurst et al. (2003a). Higher milk fat proportions of $\mathrm{C} 22: 5 \mathrm{n}-3$ and $\mathrm{C} 22: 6 \mathrm{n}-3$ may be explained by inclusion of fishmeal in concentrates used on ORG farms, in accordance with Donovan et al. (2000).

As forages did not differ in FA composition, and concentrates used on ORG farms contained less C18-FA than those used on CON farms, cows on ORG farms most likely had lower intakes of C18-FA. Therefore, to adjust for the difference in total C18-FA intake, the proportions of the different C18-FA in total C18-FA in milk were calculated. Lower proportions of C18:0 and higher proportions of $\mathrm{C} 18: 2 \mathrm{n}-6$ and $\mathrm{C} 18: 3 \mathrm{n}-3$ in total C18-FA in milk indicate that feed PUFA were to a lower extent biohydrogenated in the rumen of cows on ORG farms. Further, higher proportions of C18:1 trans FA and C18:2 cis-9,trans-11, partly deriving from the rumen biohydrogenation intermediate C18:1 trans-11, indicate an inhibition of the terminal biohydrogenation step in cows on ORG farms. An accumulation of biohydrogenation intermediates has been observed by including fish oil in the diet (Lee et al., 2008; Shingfield et al., 2012) or by feeding botanically diverse forages (Lourenço et al., 2008).

Seasonal effects on milk FA composition in this study confirm the findings of other studies (Elgersma 
Table 9. Milk FA proportions in total C18-FA in milk from dairy farms with an organic (ORG) or a conventional production system $(\mathrm{CON} ; \mathrm{n}=168)$

\begin{tabular}{|c|c|c|c|c|}
\hline \multirow{2}{*}{$\begin{array}{l}\mathrm{FA}, \mathrm{g} / \mathrm{kg} \text { of total } \\
\text { C18-FA methyl esters }\end{array}$} & \multicolumn{2}{|c|}{ Production system } & \multirow[b]{2}{*}{ SEM } & \multirow{2}{*}{$\frac{P \text {-value }}{1}$} \\
\hline & ORG & $\mathrm{CON}$ & & \\
\hline C18:0 & 278 & 305 & 5.2 & $<0.001$ \\
\hline C18:1 cis-9 & 578 & 575 & 4.5 & NS \\
\hline C18:1 cis-11 & 23 & 21 & 0.7 & 0.004 \\
\hline C18:1 trans $\mathrm{FA}$ & 78 & 59 & 3.7 & $<0.001$ \\
\hline C18:2n-6 & 49 & 44 & 1.5 & 0.003 \\
\hline C18:2 cis-9,trans-11 & 19 & 15 & 1.2 & 0.003 \\
\hline C18:2 trans-10, cis- 12 & 1 & 0 & 0.1 & NS \\
\hline C18:3n-6 & 3 & 3 & 0.2 & 0.001 \\
\hline C18:3n-3 & 19 & 14 & 1.0 & $<0.001$ \\
\hline C18:4n-3 & 1 & 1 & 0.1 & 0.002 \\
\hline
\end{tabular}

${ }^{1}$ Nonsignificant $=P>0.10$.

${ }^{2}$ Contrast of ORG vs. CON.

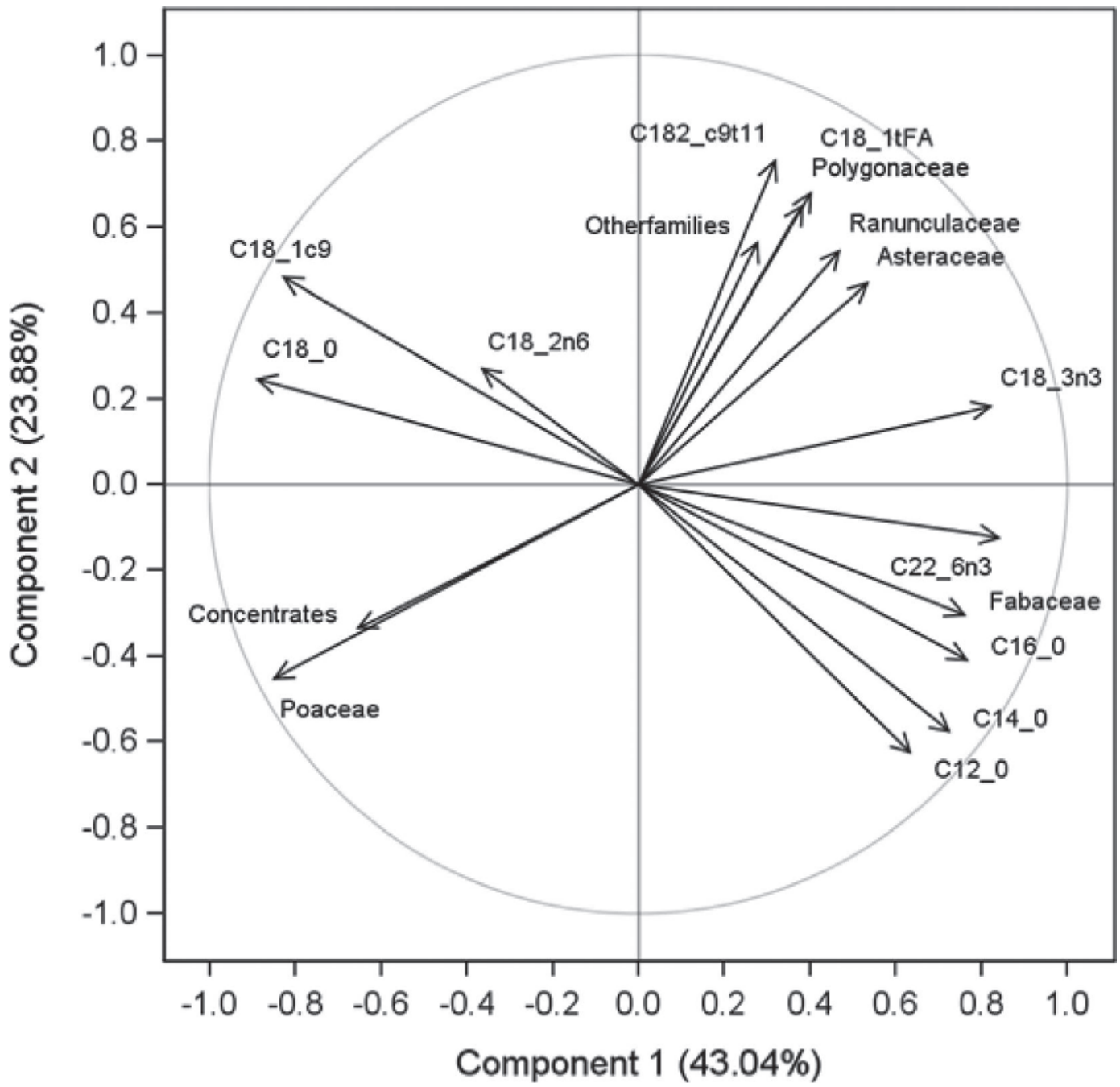

Figure 2. Correlation loading plot for first and second principal component (PC1 vs. PC2) showing the relationship between milk FA proportions of C12:0 (C12_0), C14:0 (C14_0), C16:0 (C16_0), C18:0 (C18_0), C18:1 cis-9 (C18_1c9), C18:1 trans FA (C18_1tFA), C18:2n-6 (C18_2n6), C18:2 cis-9,trans-11 (C18_2c9t11), C18:3n-3 (C18_3n3), C22:6n-3 (C22_6n3), and herbage proportions of the grass family (Poaceae), legume family (Fabaceae), knotweed family (Polygonaceae), aster family (Asteraceae), buttercup family (Ranunculaceae), other botanical families, and cows' concentrate DMI (means over 2 yr for 28 farms). 
et al., 2004; Ellis et al., 2006; Collomb et al., 2008b). High intake of PUFA from fresh herbage affects rumen fermentation pattern and gives milk fat with less SFA and more C18:1 trans-11, C18:2 cis-9,trans-11, and C18:3n-3 compared with indoor feeding (Lock and Garnsworthy, 2003; Wiking et al., 2010). In contrast to previous findings (Elgersma et al., 2004; Ellis et al., 2006; Collomb et al., 2008b), the proportions of $n-6$ FA were higher in summer milk than in winter milk, and no seasonal changes in the n-6:n-3 FA ratios were observed in the present study. This is due to high milk fat proportions of $\mathrm{C} 18: 2 \mathrm{n}-6$ in summer milk, but the underlying mechanisms are not known.

The negative correlations between milk fat proportions of C18:1 trans FA, C18:2 cis-9,trans-11, and grass herbage proportions (see Correlation of Herbage Botanical Composition and FA Composition in Milk) agree with the findings of Collomb et al. (2002). In the present study, legumes were positively correlated with C12:0, C14:0, and C16:0, which is in contrast with Collomb et al. (2002), who found a positive correlation between grass proportion and total SFA, and Dewhurst et al. (2003b), who found a negative effect of red clover proportion on milk fat proportion of C16:0.

\section{Effects on Fat-Soluble Vitamins and Se in Milk and on Milk Sensory Quality}

Milk concentrations of $\alpha$-tocopherol and $\beta$-carotene were not affected by production system. These results are in accordance with Ellis et al. (2007) and Butler et al. (2008) in the indoor feeding period. In contrast to the present study, Butler et al. (2008) found positive effects of organic farming on $\alpha$-tocopherol and $\beta$-carotene concentrations, and Ellis et al. (2007) found a negative effect on retinol concentrations in milk produced during the grazing season. These authors assumed that higher concentrations of $\alpha$-tocopherol and $\beta$-carotene were related to grazing, intake of fresh forage, or intake of grass silage, whereas the effect on retinol most likely was due to higher vitamin A concentrations in the concentrates used on conventional farms than in those used on organic farms.

The milk Se concentrations in this study were in the range reported by others, but lower than reported in South Dakota, an area with naturally high soil Se concentrations (Alaejos and Romero, 1995; LindmarkMånsson et al., 2003). The higher milk Se concentrations on ORG farms are most probably due to the inclusion of Se-rich fishmeal in the diets. Organically bound Se is more bioavailable than inorganic Se (selenite) and is translocated more efficiently to storage proteins and to milk; therefore, feeding organic Se results in higher milk Se concentrations than when feeding inorganic Se
(Calamari et al., 2010; Govasmark et al., 2010). Thus, the potentially higher amount of Se supplied and the higher Se bioavailability of the supplements may explain the higher Se concentration in milk produced on ORG farms.

In contrast to the studies of Ellis et al. (2007) and results from the outdoor feeding season in the study of Butler et al. (2008), we found no effects of production system on fat-soluble vitamins. Butler explained the differences during the outdoor feeding season by greater dietary contribution from grazing on organic farms compared with conventional high-input farms.

The higher concentrations of $\alpha$-tocopherol, $\beta$-carotene and unchanged concentrations of retinol in milk from the indoor feeding periods compared with the outdoor feeding periods were unexpected and in contrast to other studies (Lindmark-Månsson et al., 2003; Agabriel et al., 2007). Concentrations of fat-soluble vitamins in silage decrease during storage (Beeckman et al., 2010), and therefore lower values in milk would be expected during the indoor feeding periods. This unexpected effect of season on vitamins warrants further study to clarify the mechanisms. Vitamin supplements were fed as synthetic vitamins on both ORG and CON farms, which likely explains the lack of differences between systems. However, lower milk yields on ORG farms may have resulted in increased vitamin concentrations, as reported by Jensen et al. (1999).

Elevated milk fat proportions of n-3 FA suggest positive health effects of organically produced milk for humans (Kliem and Givens, 2011); conversely, higher proportions of SFA are understood to have negative health effects. Although statistically significant effects of farming system were found for FA with potential health effects, for example, for C22:5 n-3, the absolute differences are most likely too small to have any effect on biological functions.

\section{CONCLUSIONS}

Despite differences in herbage botanical composition between ORG-SG and ORG-LG farms, grassland management had minor effects on milk FA composition. The effects of production system, organic versus conventional, on milk FA composition were pronounced and most likely related to differences in concentrate DMI and FA composition, although differences in herbage botanical composition existed between ORG farms and $\mathrm{CON}$ farms. Also, the effects of season were pronounced. Milk fat from ORG farms had higher proportions of health-beneficial n-3 FA, but also higher proportions of total SFA, which are regarded to have negative effects on health. Furthermore, the outdoor feeding periods with grazing had positive effects on 
beneficial FA. Effects of grassland management and production system on fat-soluble vitamins and sensory quality were small.

\section{ACKNOWLEDGMENTS}

This work was funded by Møre and Romsdal County and TINE Norwegian Dairies SA (Oslo, Norway). TINE Norwegian Dairies SA is acknowledged for collection of feed and milk samples.

\section{REFERENCES}

Agabriel, C., A. Cornu, C. Journal, C. Sibra, P. Grolier, and B. Martin. 2007. Tanker milk variability according to farm feeding practices: Vitamins A and E, carotenoids, color, and terpenoids. J. Dairy Sci. 90:4884-4896. http://dx.doi.org/10.3168/jds.2007-0171.

Al-Mabruk, R. M., N. F. G. Beck, and R. J. Dewhurst. 2004. Effects of silage species and supplemental vitamin $\mathrm{E}$ on the oxidative stability of milk. J. Dairy Sci. 87:406-412. http://dx.doi.org/10.3168/ jds.S0022-0302(04)73180-X.

Alaejos, M. S., and C. D. Romero. 1995. Selenium concentration in milks. Food Chem. 52:1-18. http://dx.doi.org/10.1016/03088146(94)P4174-E.

Alzahal, O., M. M. Or-Rashid, S. L. Greenwood, M. S. Douglas, and B. W. McBride. 2009. The effect of dietary fiber level on milk fat concentration and fatty acid profile of cows fed diets containing low levels of polyunsaturated fatty acids. J. Dairy Sci. 92:11081116. http://dx.doi.org/10.3168/jds.2008-1472.

Anonymous. 2012. Fôrtabell 2008 (Feed table). University of Life Sciences, Norway and Norwegian Food Safety Authority; Accessed Sep. 18, 2012. http://statisk.umb.no/iha/fortabell/index.php.

AOAC. 1990. Official methods of analysis. 15th ed. Assoc. Off. Anal. Chem., Arlington, VA.

Appleby, P. N., M. Thorogood, J. I. Mann, and T. J. Key. 1999. The Oxford vegetarian study: An overview. Am. J. Clin. Nutr. 70:525S-531S.

Beeckman, A., J. Vicca, G. Van Ranst, G. P. J. Janssens, and V. Fievez. 2010. Monitoring of vitamin E status of dry, early and midlate lactating organic dairy cows fed conserved roughages during the indoor period and factors influencing forage vitamin $\mathrm{E}$ levels. J. Anim. Physiol. Anim. Nutr. (Berl.) 94:736-746. http://dx.doi. org/10.1111/j.1439-0396.2009.00956.x.

Bligh, E. G., and W. J. Dyer. 1959. A rapid method of total lipid extraction and purification. Can. J. Biochem. Physiol. 37:911-917.

Bolstad, T., T. H. Garmo, A. Haug, H. Volden, A. Bernhoft, and O. M. Harstad. 2007. Effect of white clover rich grass pasture allowance on $\alpha$-tocopherol and selenium content in cow milk. J. Anim. Feed Sci. 16(Suppl. 1):84-89.

Boufaied, H., P. Y. Chouinard, G. F. Tremblay, H. V. Petit, R. Michaud, and G. Belanger. 2003. Fatty acids in forages. I. Factors affecting concentrations. Can. J. Anim. Sci. 83:501-511. http:// dx.doi.org/10.4141/A02-098

Broderick, G. A. 2003. Effects of varying dietary protein and energy levels on the production of lactating dairy cows. J. Dairy Sci. 86:1370-1381. http://dx.doi.org/10.3168/jds.S00220302(03)73721-7.

Butler, G., J. H. Nielsen, T. Slots, C. Seal, M. D. Eyre, R. Sanderson, and C. Leifert. 2008. Fatty acid and fat-soluble antioxidant concentrations in milk from high- and low-input conventional and organic systems: Seasonal variation. J. Sci. Food Agric. 88:14311441. http://dx.doi.org/10.1002/jsfa.3235.

Calamari, L., F. Petrera, and G. Bertin. 2010. Effects of either sodium selenite or Se yeast (Sc CNCM I-3060) supplementation on selenium status and milk characteristics in dairy cows. Livest. Sci. 128:154-165. http://dx.doi.org/10.1016/j.livsci.2009.12.005.
Chilliard, Y., A. Ferlay, and M. Doreau. 2001. Effect of different types of forages, animal fat or marine oils in cow's diet on milk fat secretion and composition, especially conjugated linoleic acid (CLA) and polyunsaturated fatty acids. Livest. Prod. Sci. 70:31-48. http://dx.doi.org/10.1016/S0301-6226(01)00196-8.

Collomb, M., W. Bisig, U. Bütikofer, R. Sieber, M. Bregy, and L. Etter. 2008a. Fatty acid composition of mountain milk from Switzerland: Comparison of organic and integrated farming systems. Int. Dairy J. 18:976-982. http://dx.doi.org/10.1016/j.idairyj.2008.05.010.

Collomb, M., W. Bisig, U. Bütikofer, R. Sieber, M. Bregy, and L. Etter. 2008b. Seasonal variation in the fatty acid composition of milk supplied to dairies in the mountain regions of Switzerland. Dairy Sci.Technol. 88:631-647. http://dx.doi.org/10.1051/dst:2008029.

Collomb, M., U. Bütikofer, R. Sieber, B. Jeangros, and J. O. Bosset. 2002. Correlation between fatty acids in cows' milk fat produced in the lowlands, mountains and highlands of Switzerland and botanical composition of the fodder. Int. Dairy J. 12:661-666. http:// dx.doi.org/10.1016/S0958-6946(02)00062-6.

Coulon, J. B., and B. Rémond. 1991. Variations in milk output and milk protein content in response to the level of energy supply to the dairy cow: A review. Livest. Prod. Sci. 29:31-47. http:// dx.doi.org/10.1016/0301-6226(91)90118-A.

Danielsson, H., E. Nadeau, A. M. Gustavsson, S. K. Jensen, K. Egaard, and N. Nilsdotter-Linde. 2008. Contents of $\alpha$-tocopherol and $\beta$-carotene in grasses and legumes harvested at different maturities. Pages 432-434 in Grassland Science in Europe, Vol. 13. Swedish University of Agricultural Sciences, Uppsala, Sweden.

Daugstad, K., A. Ø. Kristoffersen, and L. Nesheim. 2012. Næringsinnhald i husdyrgjødsel. Analyser av husdyrgjødsel frå storfe, sau, svin og fjørfe 2006-2011. Bioforsk Rapport 7:1-29.

Dewhurst, R. J., R. T. Evans, N. D. Scollan, J. M. Moorby, R. J. Merry, and R. J. Wilkins. 2003a. Comparison of grass and legume silages for milk production. 2. In vivo and in sacco evaluations of rumen function. J. Dairy Sci. 86:2612-2621. http://dx.doi. org/10.3168/jds.S0022-0302(03)73856-9.

Dewhurst, R. J., W. J. Fisher, J. K. S. Tweed, and R. J. Wilkins. 2003b. Comparison of grass and legume silages for milk production. 1. Production responses with different levels of concentrate. J. Dairy Sci. 86:2598-2611. http://dx.doi.org/10.3168/jds.S00220302(03)73855-7.

Donovan, D. C., D. J. Schingoethe, R. J. Baer, J. Ryali, A. R. Hippen, and S. T. Franklin. 2000. Influence of dietary fish oil on conjugated linoleic acid and other fatty acids in milk fat from lactating dairy cows. J. Dairy Sci. 83:2620-2628. http://dx.doi.org/10.3168/jds. S0022-0302(00)75155-1.

Elgersma, A., G. Ellen, H. d. Horst, H. Boer, P. R. Dekker, and S. Tamminga. 2004. Quick changes in milk fat composition from cows after transition from fresh grass to a silage diet. Anim. Feed Sci. Technol. 117:13-27.

Ellis, K. A., G. Innocent, D. Grove-White, P. Cripps, W. G. McLean, C. V. Howard, and M. Mihm. 2006. Comparing the fatty acid composition of organic and conventional milk. J. Dairy Sci. 89:19381950. http://dx.doi.org/10.3168/jds.S0022-0302(06)72261-5.

Ellis, K. A., A. Monteiro, G. T. Innocent, D. Grove-White, P. Cripps, W. Graham McLean, C. V. Howard, and M. Mihm. 2007. Investigation of the vitamins $\mathrm{A}$ and $\mathrm{E}$ and $\beta$-carotene content in milk from UK organic and conventional dairy farms. J. Dairy Res. 74:484-491. http://dx.doi.org/10.1017/S0022029907002816.

European Commission. 2006. First Commission Directive 71/250/ EEC of 15 June 1971 establishing community methods of analysis for the official control of feeding-stuffs. Off. J. Eur. Union L 155(12.7.1971):13-37.

Govasmark, E., A. Brandt-Kjelsen, J. Szpunar, K. Bierla, G. Vegarud, and B. Salbu. 2010. Bioaccessibility of Se from Se-enriched wheat and chicken meat. Pure Appl. Chem. 82:461-471. http://dx.doi. org/10.1351/PAC-CON-09-06-01.

Govasmark, E., A. Steen, A. K. Bakken, T. Strom, and S. Hansen. 2005. Factors affecting the concentration of $\mathrm{Zn}, \mathrm{Fe}$ and $\mathrm{Mn}$ in herbage from organic farms and in relation to dietary requirements of ruminants. Acta Agric. Scand. B Soil Plant Sci. 55:131-142. 
Haug, A., A. Høstmark, and O. Harstad. 2007. Bovine milk in human nutrition-A review. Lipids Health Dis. 6:25.

Hopkins, A. 1986. Botanical composition of permanent grassland in England and Wales in relation to soil, environment and management factors. Grass Forage Sci. 41:237-246. http://dx.doi. org/10.1111/j.1365-2494.1986.tb01809.x.

Insel, P., R. E. Turner, and D. Ross. 2007. Nutrition. 3rd ed. Jones and Barlett Publishers, Sudbury, MA

Jahreis, G., J. Fritsche, and H. Steinhart. 1996. Monthly variations of milk composition with special regard to fatty acids depending on season and farm management systems conventional versus ecological. Eur. J. Lipid Sci. Technol. 98:356-359. http://dx.doi. org/10.1002/lipi.19960981103.

Jensen, S. K., C. Jensen, K. Jakobsen, R. M. Engberg, J. O. Andersen, C. Lauridsen, P. Sørensen, L. H. Skibsted, and G. Bertelsen. 1998. Supplementation of broiler diets with retinol acetate, $\beta$-carotene or canthaxanthin: Effect on vitamin status and oxidative status of broilers in vivo and on meat stability. Acta Agric. Scand. A Anim. Sci. 48:28-37. http://dx.doi.org/10.1080/09064709809362400.

Jensen, S. K., A. K. B. Johannsen, and J. E. Hermansen. 1999 Quantitative secretion and maximal secretion capacity of retinol, $\beta$-carotene and $\alpha$-tocopherol into cows' milk. J. Dairy Res. 66:511-522.

Jensen, S. K., and K. N. Nielsen. 1996. Tocopherols, retinol, $\beta$-carotene and fatty acids in fat globule membrane and fat globule core in cows' milk. J. Dairy Res. 63:565-574. http://dx.doi.org/10.1017/ S0022029900032106.

Jones, R. M., and J. N. G. Hargreaves. 1979. Improvements to the dry-weight-rank method for measuring botanical composition. Grass Forage Sci. 34:181-189. http://dx.doi. org/10.1111/j.1365-2494.1979.tb01465.x.

Kliem, K. E., and D. I. Givens. 2011. Dairy products in the food chain Their impact on health. Annu. Rev. Food Sci. Technol. 2:21-36. http://dx.doi.org/10.1146/annurev-food-022510-133734.

Knicky, M., T. Ericsson, and R. Spörndly. 2012. Fatty acids composition of a variety of forages before and after ensiling. Pages 250-251 in Proc. XVI Int. Silage Conf., K. Kuoppala, M. Rinne, and A. Vanhatalo, ed. MTT Agrifood Research Finland and University of Helsinki, Helsinki, Finland.

Lee, M. R. F., K. J. Shingfield, J. K. S. Tweed, V. Toivonen, S. A. Huws, and N. D. Scollan. 2008. Effect of fish oil on ruminal biohydrogenation of $\mathrm{C} 18$ unsaturated fatty acids in steers fed grass or red clover silages. Animal 2:1859-1869. http://dx.doi. org/10.1017/S1751731108002899.

Lindmark-Månsson, H., R. Fondén, and H. E. Pettersson. 2003. Composition of Swedish dairy milk. Int. Dairy J. 13:409-425. http:// dx.doi.org/10.1016/S0958-6946(03)00032-3.

Lindqvist, H., E. Nadeau, and S. K. Jensen. 2012. Alpha-tocopherol and $\beta$-carotene in legume-grass mixtures as influenced by wilting, ensiling and type of silage additive. Grass Forage Sci. 67:119-128. http://dx.doi.org/10.1111/j.1365-2494.2011.00827.x.

Lock, A. L., and P. C. Garnsworthy. 2003. Seasonal variation in milk conjugated linoleic acid and $\Delta^{9}$-desaturase activity in dairy cows.
Livest. Prod. Sci. 79:47-59. http://dx.doi.org/10.1016/S03016226(02)00118-5.

Lourenço, M., G. Van Ranst, B. Vlaeminck, S. De Smet, and V. Fievez. 2008. Influence of different dietary forages on the fatty acid composition of rumen digesta as well as ruminant meat and milk. Anim. Feed Sci. Technol. 145:418-437.

Mannetje, L., and K. P. Haydock. 1963. The dry-weight-rank method for botanical analysis of pasture. J. Br. Grassl. Soc. 18:268-275. http://dx.doi.org/10.1111/j.1365-2494.1963.tb00362.x.

McDowell, L. R. 2000. Vitamins in animal and human nutrition. 2nd ed. Iowa State University Press, Ames. 10.1002/9780470376911.

Molkentin, J., and D. Precht. 1995. Optimized analysis of trans-octadecenoic acids in edible fats. Chromatographia 41:267-272. http://dx.doi.org/10.1007/BF02688039.

Moorby, J. M., M. R. F. Lee, D. R. Davies, E. J. Kim, G. R. Nute, N. M. Ellis, and N. D. Scollan. 2009. Assessment of dietary ratios of red clover and grass silages on milk production and milk quality in dairy cows. J. Dairy Sci. 92:1148-1160. http://dx.doi. org/10.3168/jds.2008-1771.

Palmquist, D. L., A. D. Beaulieu, and D. M. Barbano. 1993. Feed and animal factors influencing milk fat composition. J. Dairy Sci. 76:1753-1771. http://dx.doi.org/10.3168/jds.S00220302(93) $77508-6$

Roe, M. B., and C. J. Sniffen. 1990. Techniques for measuring protein fractions in feedstuffs. Pages 81-86 in Cornell Nutrition Conference Proceedings. Cornell University, Ithaca, NY.

SAS. 2009. SAS/STAT 9.2 User's Guide. 2nd ed. SAS Inst. Inc., Cary, $\mathrm{NC}$.

Shingfield, K. J., P. Kairenius, A. Ärölä, D. Paillard, S. Muetzel, S. Ahvenjärvi, A. Vanhatalo, P. Huhtanen, V. Toivonen, J. M. Griinari, and R. J. Wallace. 2012. Dietary fish oil supplements modify ruminal biohydrogenation, alter the flow of fatty acids at the omasum, and induce changes in the ruminal Butyrivibrio population in lactating cows. J. Nutr. 142:1437-1448. http://dx.doi. org/10.3945/jn.112.158576.

Steinshamn, H., and E. Thuen. 2008. White or red clover grass silage in organic dairy milk production. Grassland productivity and milk production responses with different levels of concentrate. Livest. Sci. 119:202-215.

Van Der Honing, Y., and G. Alderman. 1988. III. 2. Rumin. Livest. Prod. Sci. 19:217-278. http://dx.doi.org/10.1016/0301$6226(88) 90092-9$

Van Es, A. J. H. 1978. Feed evaluation for ruminants. I. The system in use from May 1977 onwards in the Netherlands. Livest. Prod. Sci. 5:331-345. http://dx.doi.org/10.1016/0301-6226(78)90029-5.

Van Soest, P. J., J. B. Robertson, and B. A. Lewis. 1991. Methods for dietary fiber, neutral detergent fiber, and nonstarch polysaccharides in relation to animal nutrition. J. Dairy Sci. 74:3583-3597. http://dx.doi.org/10.3168/jds.S0022-0302(91)78551-2.

Wiking, L., P. K. Theil, J. H. Nielsen, and M. T. Sørensen. 2010. Effect of grazing fresh legumes or feeding silage on fatty acids and enzymes involved in the synthesis of milk fat in dairy cows. J. Dairy Res. 77:337-342. http://dx.doi.org/10.1017/S002202991000021X. 